\title{
Correcting for underestimation of microzooplankton grazing in bottle incubation experiments with mesozooplankton
}

\author{
Jens C. Nejstgaard ${ }^{1, *}$, Lars-Johan Naustvoll ${ }^{2}$, Andrey Sazhin ${ }^{3}$ \\ ${ }^{1}$ Department of Fisheries and Marine Biology, University of Bergen, Bergen High Technology Center, PO Box 7800, \\ 5020 Bergen, Norway \\ ${ }^{2}$ Flødevigen Research Station, Institute of Marine Research, 4817 His, Norway \\ ${ }^{3}$ P.P. Shirshov Institute of Oceanology RAS, Nahimovsky Av. 36, Moscow 117851, Russia
}

\begin{abstract}
Bottle incubation experiments are widely used in mesozooplankton grazing studies. However, we have shown here that traditional particle removal experiments with Calanus finmarchicus and C. helgolandicus as grazers on natural plankton may yield low or even statistically significant $(\mathrm{p}<0.05)$ negative grazing estimates, even though negative grazing rates are impossible. Low grazing rates are often reported, especially on smaller prey types, despite abundant food and significant egg production. Microzooplankton, such as ciliates, show higher biomass-specific grazing rates on algae than do copepods and other mesozooplankton. Instead, copepods often selectively feed on the microzooplankton. Thus, apparent negative rates would be expected when the release of microzooplankton grazing pressure outweighs the copepod grazing rates on the same food items in the incubation bottle. We show that this potentially large bias increases with microzooplankton community grazing pressure in the control. A simplified general method to correct for this bias is presented and compared with the original method (Nejstgaard et al. 1997, Mar Ecol Prog Ser 147:197-217). Although complexity and the need for taxonomic accuracy are reduced in the general method, the results are not significantly different between the 2 methods. Both methods also show a good fit with ingestion rates estimated from faecal pellet production. We suggest that the general method be combined with automated sample treatment in future studies. In addition, we argue that carefully estimated faecal volume production provides a simple and quick overall feeding estimate with important advantages over the common gut pigment technique, and it may be used as an independent method in bottle incubation experiments.
\end{abstract}

KEY WORDS: Calanus finmarchicus · Calanus helgolandicus · Microzooplankton · Grazing methods · Clearance $\cdot$ Ingestion $\cdot$ Faecal pellet production $\cdot$ Natural plankton $\cdot$ Bottle effect

\section{INTRODUCTION}

A number of methods have been developed to assess mesozooplankton grazing rates, ranging from fast and coarse bulk methods based on pigment analysis to detailed time-consuming microscopy studies of either gut content or the food medium (see Båmstedt et al. 2000).

*E-mail: jens.nejstgaard@ifm.uib.no
Copepods are often omnivorous, and different species ingest food items ranging from small-sized algae of a few $\mu \mathrm{m}$ up to fish larva and mesozooplankton of a few mm (Turner et al. 1984, 1985, Landry \& Fagerness 1988, Gifford 1991, Hansen et al. 1994, Nejstgaard et al. 1995). Many copepods feed selectively on the microzooplankton when available, and algal ingestion alone is often insufficient to meet metabolic costs in the sea (e.g. Stoecker \& Capuzzo 1990, Kleppel 1993, Dam et al. 1994, Ohman \& Runge 1994, Atkinson 1996, 
Peterson \& Dam 1996, Verity \& Paffenhöfer 1996, Nejstgaard et al. 1997, Roman et al. 2000, and this study). Quantification of copepod feeding rates in the field by methods based on gut pigment (Mackas \& Bohrer 1976), ${ }^{14} \mathrm{C}$-labeled algae, or plant pigment analysis by HPLC (e.g. Kleppel \& Pieper 1984, MeyerHarms et al. 1999) is limited to herbivory, and may substantially underestimate total zooplankton ingestion rates and bias prey selectivity estimates. Such data must be treated with caution. The potential problem with food web interactions in incubation experiments as discussed here may further limit the value of phytoplankton-based methods, if not corrected.

The dual labelling technique (Roman \& Rublee 1981, Roman \& Gauzens 1997) yields data on zooplankton omnivory in situ. However, this method does not give detailed data on feeding selectivity and has a number of potential problems, including the fact that grazing on algae can only be measured during daytime (Roman \& Rublee 1981). Many zooplankton show maximum feeding activity during night, even at high latitudes and at low food concentrations (Atkinson et al. 1996). Thus, this technique may result in significant underestimation of grazing rates, especially on larger algae and microzooplankton (cf. Roman \& Rublee 1981). Therefore methods to quantify the overall daily grazing activity in natural plankton should ideally include the full $24 \mathrm{~h}$ period.

Microscopy of gut content and faecal pellets gives some information on omnivory. But important softbodied heterotrophic prey such as aloricate ciliates have not been possible to quantify by gut content analysis, although such attempts have been made (Ohman 1992, Juhl et al. 1996, M. D. Ohman pers. comm.).

Analysis of particle removal in bottle incubations is presently the only available method that allows direct feeding rate quantification of non-pigmented taxa (Båmstedt et al. 2000). Such experiments analysed according to the equations of Frost (1972), Omori \& Ikeda (1984), or modifications thereof (Marin et al. 1986), are widely used for quantification of natural diets in copepods and other mesozooplankton (e.g. Gifford 1993).

A problem with bottle incubations is that prey suspensions containing several trophic levels, such as natural plankton, often yield low or in some cases even statistically significant negative mesozooplankton grazing estimates on some prey algae types and chlorophyll (chl) a. Although significant negative grazing rates per se are impossible, such rates are often ignored or assumed to simply reflect low feeding rates on those prey types if they cannot be explained by nutrient effects (Lehman 1980). But it is well known that microzooplankton, such as ciliates, show higher biomass-specific grazing rates on algae than do copepods and other mesozooplankton (Hansen et al. 1997). Copepods instead often feed selectively on the microzooplankton (e.g. Hansen et al. 1993, Kleppel 1993, Verity \& Paffenhöfer 1996, Nejstgaard et al. 1997, Calbet \& Landry 1999). Thus, negative rates would be expected when the release of microzooplankton grazing pressure outweighs the copepod grazing rates on the smaller food items in the incubation bottle. This has significant implications not only as a mechanism during development of blooms in the field, as pointed out by Hansen et al. (1993), but also for the validity of mesozooplankton grazing rates obtained from traditional bottle incubation studies (cf. Calbet \& Landry 1999 and others).

We show that this artefact may have a substantial impact on grazing rate estimates in natural plankton, and that this artefact increases when microzooplankton community grazing pressure is high in the natural food suspension. A first method to correct for this bias was presented in Nejstgaard et al. (1997). Based on a larger data set, we present a simplified version of the method, compare it with the original method and with the classical faecal pellet production method, and then discuss the results of the methods further.

\section{MATERIALS AND METHODS}

Experimental materials. The experiments were performed at the Marine Biological Field Station of the University of Bergen, Norway, on 7 occasions between 9 September 1996 and 2 May 1998 (Table 1). Natural plankton suspensions for the experiments were retrieved from $27 \mathrm{~m}^{3}$ ( $2 \mathrm{~m}$ diameter, $9.25 \mathrm{~m}$ deep) transparent ( $90 \%$ penetration, PAR) polyethylene in situ sea water enclosures (mesocosms). In 1996 and 1997 the mesocosms were filled with natural water in situ, and stratification was established in the upper 4 to $5 \mathrm{~m}$ by adding ca $0.6 \mathrm{~m}^{3}$ of fresh water and mixing the top layer with an air lift. After stratification was established, nutrients were added daily to the mesocosms, corresponding to final concentrations of $1.5 \mu \mathrm{mol} \mathrm{l}^{-1}$ nitrate and $0.1 \mu \mathrm{mol} \mathrm{l}^{-1}$ phosphate. Silicate was also added to the upper layer of half of the mesocosms to a final concentration of $1.5 \mathrm{~mol} \mathrm{l}^{-1}$, in order to stimulate diatom blooms. The other mesocosms were expected to yield flagellate blooms. In 1998 the mesocosms were set up as described above, except that nutrients were added corresponding to final concentrations of $5 \mu \mathrm{mol}$ $\mathrm{l}^{-1}$ nitrate, $0.3 \mu \mathrm{mol} \mathrm{l}^{-1}$ phosphate and $5 \mu \mathrm{mol} \mathrm{l}^{-1}$ silicate on 2 occasions: at the start of the mesocosms (18 April) and on 30 April, which was a day before the grazing experiment was performed. Only water from the top mixed layers was used in grazing experiments. The 


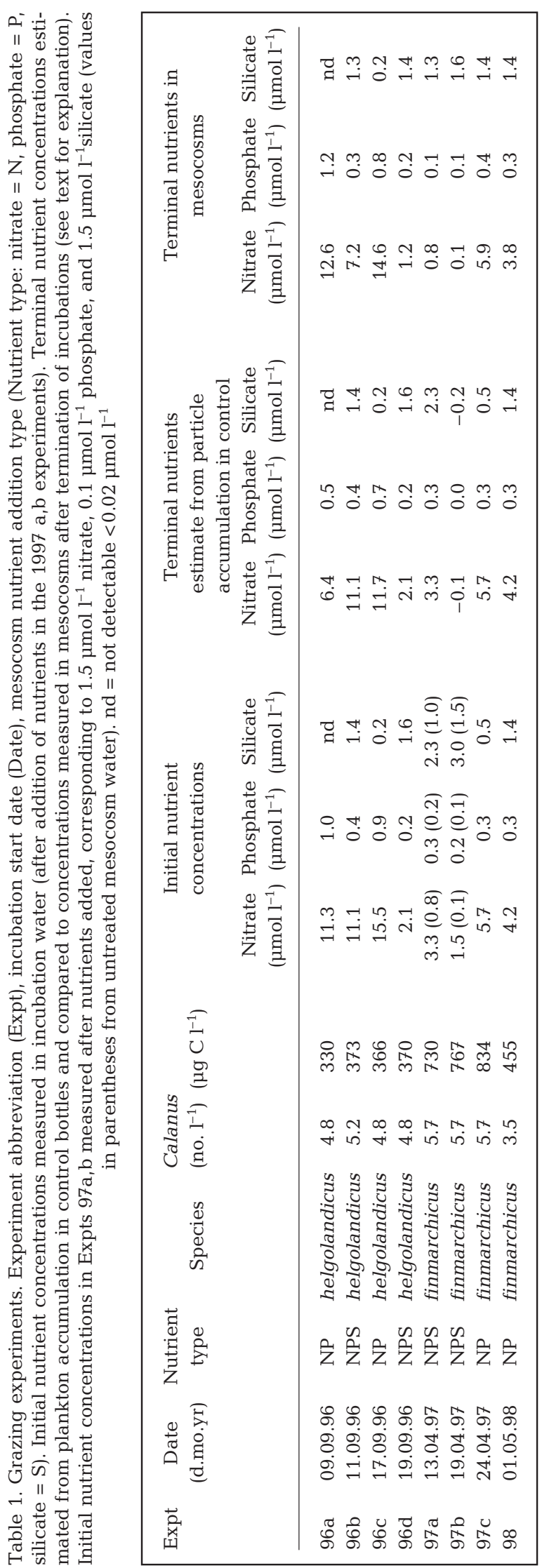

salinity varied between ca 30 PSU in 1996, and 32 in 1997 and 1998. The temperature varied from $6^{\circ} \mathrm{C}$ in $1997,7.5^{\circ} \mathrm{C}$ in 1998 , to $9-13^{\circ} \mathrm{C}$ in 1996 . For further description of the mesocosm experimental design see Svensen et al. (2001); a general description of the mesocosm facility is available at: www.ifm.uib.no/LSF/ inst2.html.

Females and stage V copepodites of Calanus finmarchicus and $C$. helgolandicus for the grazing experiments were collected from the surface water $(0-20 \mathrm{~m})$ of the nearby Raunefjorden, using a $1.2 \mathrm{~m}$ diameter $700 \mu \mathrm{m}$ mesh net, with a 141 non-filtering cod end. Actively swimming undamaged copepods were sorted out using wide mouth pipettes at in situ temperature shortly after collection.

Grazing experiments and sampling. Dates, abbreviated names, mesocosm water nutrient treatments and copepod species used in the experiments are summarized in Table 1. Both dilution experiments (Landry 1993) and bottle incubations with Calanus spp. as grazers were run simultaneously on each occasion. Water for the dilution experiments was collected in 251 polycarbonate bottles and filtered through $0.2 \mu \mathrm{m}$ sterile inline filters (500 $\mathrm{cm}^{2}$, Supor ${ }^{\mathrm{TM}}$ DCF, Gelman) using tissue culture hoses and low pressure (ca $0.5 \mathrm{~m}$ water column). Filtration was done at in situ temperature immediately before set-up of the experiments. Target concentrations for the dilution series were triplicates of 10, 30 and $100 \%$ undiluted sea water. Undiluted sea water was screened through a submerged $200 \mu \mathrm{m}$ net to avoid mesozooplankton. For determination of copepod feeding rates 8 to 14 copepods were added to each of a further 3 to 5 bottles (2.3 l polycarbonate) with $100 \%$ undiluted sea water. The $100 \%$ bottles from the dilution series also served as controls for the copepod bottles. Absolute dilutions were checked by the chl a concentrations at the start in all dilutions, and dilutions were corrected for change in total microzooplankton biomass during incubations by counts at the start in $100 \%$-bottles and at the end in all bottles (cf. Landry 1993).

The amount of copepods added to the bottles may seem relatively high (Table 1 ). Note, however, that the total potential prey concentrations were also high (see Tables 4 \& 5), and comparable to blooms in eutrophic fjords (see 'Results and discussion'). The average decrease in total prey $\mathrm{C}$ concentrations and chl a were only 11 and $6 \%$ respectively (see Table 6). This is much less than the ca 30 to $40 \%$ decrease needed to yield significant differences between cell counts from grazer and control bottles in traditionally performed incubation experiments (Gifford 1993, Båmstedt et al. 2000). Only the most selected prey items showed a decrease beyond $50 \%$ (see 'Results and discussion'). 
In order to facilitate comparison of algal growth in the bottles and in the fertilized mesocosms, excess nutrient addition to the incubation bottles was avoided. Extra nutrients were added to the bottles only when they were anticipated to become limiting during the incubations (cf. Landry 1993, Båmstedt et al. 2000), as in the $97 \mathrm{a}$ and $\mathrm{b}$ experiments (Table 1, also see 'Results and discussion').

Copepods were acclimated in the experimental water for $24 \mathrm{~h}$ prior to the incubations. All bottles were incubated in situ, outside the mesocosms overnight (22 to $25 \mathrm{~h}$ ), hanging from a floating ring at $1.5 \mathrm{~m}$ depth in order to yield light conditions comparable to average conditions for the upper layer of the mesocosms, and to create gentle agitation, preventing sedimentation of plankton and yet minimising the disruption of faecal pellets. At the termination of the experiment the bottles were inverted and gently sampled by siphoning off samples for chl a, epifluorescence (not in 1996) and protist analysis. In 1996 copepods were thereafter screened on $200 \mu \mathrm{m}$ submerged net and were immediately counted and examined for stage and viability under a dissecting microscope, before being fixed in $4 \%$ hexamine buffered formaldehyde. The remaining water was screened for particles $>40 \mu \mathrm{m}$, fixed in formaldehyde. Both the $>200 \mu \mathrm{m}$ and $>40 \mu \mathrm{m}$ fractions were later enumerated for faecal pellets and less abundant larger-sized zooplankton. Ceratium spp. and other large dinoflagellates were checked for cell content (cf. Elbrächter 1973). In 1997 and 1998 copepods and larger items were collected on a $40 \mu \mathrm{m}$ screen; copepods were checked for viability, and the samples were fixed in formaldehyde for later analysis.

Analysis of the samples. Nitrate, phosphate and silicate concentrations were determined on fresh samples using a Skalar SAN ${ }^{\text {plus }}$ segmented flow analyzer. Replicate chl a samples were filtered onto $25 \mathrm{~mm} 0.45 \mu \mathrm{m}$ cellulose nitrate filters. Samples were frozen $\left(-22^{\circ} \mathrm{C}\right)$ until extraction overnight in $90 \%$ acetone and measured on a Turner Designs Model 10-AU Fluorometer according to the method of Welschmeyer (1994). Epifluorescence samples were filtered onto black $0.4 \mu \mathrm{m}$ nucleopore filters, stained with primulin and fixed with $3.6 \%$ glutaraldehyde and $10 \%$ glycerine for determination of trophic status of the protists, according to our own modification of the method of Grebecki (1962), Hobbie et al. (1977) and Caron (1983). Phytoplankton samples (in 1996) and samples for all protists (in 1997/98) were preserved with a glutardialdehydelugol mix (35\% final v/v) (Rousseau et al. 1990), settled in 2,10 or $50 \mathrm{ml}$ sediment chambers, and counted and measured at $200 \times, 400 \times$ and/or $600 \times$ magnification. In 1996 microzooplankton samples were fixed in acid Lugol's solution (final concentration 1\%), settled in $50 \mathrm{ml}$ sediment chambers, counted at $200 \times$ and mea- sured at $400 \times$ magnification. Epifluorescence samples were analysed on Olympus or Zeiss Axioplan microscopes. Phytoplankton and microzooplankton were counted and measured on inverted Wild M40 or LUMAM-P8 microscopes. The $40 \mu \mathrm{m}$ net samples, for faecal pellet and larger zooplankton, were examined under a Wild M10 dissecting microscope.

Cell to carbon conversion. Cell volume was calculated using simple geometrical formulae (Edler 1979, Ohman \& Snyder 1991). Cell volume was converted into $\mathrm{C}$ according to the equations of Menden-Deuer \& Lessard (2000): $\log C=(\log a)+(b \log V)$, where $C$ is mass of carbon (pg) per cell, $\mathrm{V}$ is cell volume $\left(\mu^{3}\right)$, and $\log a=-0.541$ and $b=0.811$ for diatoms, and $\log a=$ -0.665 and $b=0.939$ for all other protist plankton except aloricate ciliates. The volume to $\mathrm{C}$ conversion factor for aloricate ciliates strongly depends on fixative type and concentration (Stoecker et al. 1994). There was, however, little difference between aloricate species fixed in 1 or $2 \%$ acid Lugol's solution (Ohman \& Snyder 1991). We therefore used the factor of $0.19 \mathrm{pg} \mathrm{C}$ $\mu^{-3}$ experimentally derived for aloricate ciliates fixed in 2\% acid Lugol's solution (Putt \& Stoecker 1989). Metazooplankton abundance was converted into carbon by species and stage specific values from the literature (Båmstedt 1986, Blom et al. 1989, Båmstedt et al. 1990, Widdows 1991, Karlson \& Båmstedt 1994), using the conversion factor of $0.547 \mathrm{C}: \mathrm{DW}$ for copepods from high latitudes (Båmstedt 1986). When species specific values were not found we used the general volume to $\mathrm{C}$ conversion factor of $0.126 \mathrm{~g} \mathrm{C} \mathrm{cm}^{-3}$ from Hansen et al. (1997).

Assigning trophic status to protists. All algae were assumed to be mainly autotrophic, except when they did not contain chloroplasts in the epifluorescence samples. The more rare algal species not found in the epifluorescence samples in 1997 and 1998, and all algae in 1996 were assigned to trophic status according to the literature (Lessard \& Swift 1986, Gaines \& Elbrächter 1987, Hansen 1991, Bralewska \& Witek 1995, Taylor et al. 1995, Tomas 1997, Tong et al. 1998). Except for the possible obligate autotrophic Mesodinium rubrum (Lohmann 1908) Jankowski 1976 (= Myrionecta rubra) (Gustafson et al. 2000), all ciliates were assumed to be mainly heterotrophic. Although many ciliates retain chloroplasts (e.g. Laval-Peuto \& Rassoulzadegan 1988, Stoecker et al. 1989), they are here considered to be dependent on algal food such as the obligate mixotroph Laboea strobila (Stoecker et al. 1988), and are thus defined as heterotrophic in the following calculations.

Calculations of growth and grazing rates. Microzooplankton: Target dilutions were adjusted for changes in total microzooplankton body carbon density, and algae growth rates, microzooplankton grazing coefficients and daily grazing impact were calculated 
according to Landry (1993). Due to the limited number of samples per experiment $(\mathrm{n}=9)$ the microzooplankton grazing data were not tested for non-linearity, and may therefore be considered as minimum estimates (cf. Gallegos 1989). In order to evaluate whether the microzooplankton feeding rates obtained for each feeding guild (Table 2) seemed reasonable, we calculated microzooplankton body volume specific clearance $\left(\mathrm{C}_{\mathrm{bv}}\right)$ and ingestion $\left(\mathrm{I}_{\mathrm{bv}}\right)$ rates based on the microzooplankton grazing coefficient (Table 3) and average microzooplankton volume specific abundance as described in Hansen et al. (1997).

Uncorrected copepod grazing rates: Copepod clearance and ingestion rates were first calculated according to the equation by Frost (1972), which is also used generally for natural plankton (e.g. Gifford 1993). Because this method does not account for the effect of feeding interactions in natural plankton discussed here, this method will hereafter be referred to as the 'uncorrected' method.

The Guild method: We argue that when copepod predation significantly reduces microzooplankton grazing pressure in the copepod bottles, this leads to an underestimation of uncorrected copepod grazing rates on prey also grazed by the microzooplankton (see 'Results and discussion'). In order to correct for this bias we established a microzooplankton feeding guild table based on available literature (Table 2), and calculated corrected copepod feeding rates by the original method described in Nejstgaard et al. (1997). This method will be referred to as the 'Guild' method hereafter. The Guild method assumes that: (1) each microzooplankter only ingests prey from within a defined size spectrum (i.e. feeding guild, Table 2); (2) microzooplankton ingest all prey types within their feeding guild in direct proportion to the respective prey type

Table 2. Microzooplankton feeding guilds. Prey types assigned to each guild are within the size range expected to give at least $10 \%$ of maximum feeding rates. Size ranges: $\mu \mathrm{m}$ ESD (overlap in some overall size distributions are due to slight adjustments of different prey size groups in different experiments)

\begin{tabular}{|c|c|c|c|c|c|c|c|c|c|c|c|c|c|c|}
\hline \multirow[t]{2}{*}{ Predator species } & \multicolumn{13}{|c|}{ Prey type } & \multirow[t]{2}{*}{ Reference } \\
\hline & $\begin{array}{l}f \\
\forall \\
0 \\
\hat{0} \\
\sigma \\
ت \\
ت\end{array}$ & 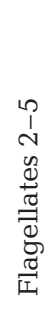 & 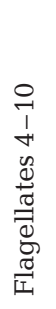 & 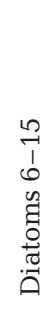 & 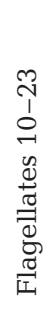 & $\begin{array}{l}0 \\
m \\
1 \\
0 \\
\ddot{y} \\
0 \\
\stackrel{0}{0} \\
:=0 \\
:=0\end{array}$ & 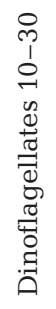 & 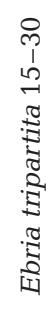 & $\begin{array}{l}0 \\
\stackrel{1}{\wedge} \\
\hat{n} \\
\tilde{\Xi} \\
0 \\
\stackrel{0}{0} \\
\stackrel{0}{0}\end{array}$ & 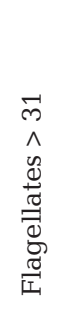 & 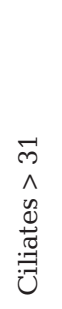 & 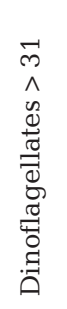 & 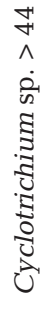 & \\
\hline Copepodites $^{\mathrm{a}}$ & $\mathrm{X}$ & $\mathrm{X}^{\mathrm{b}}$ & $\mathrm{X}$ & $\mathrm{X}$ & $\mathrm{X}$ & $\mathrm{X}$ & $\mathrm{X}$ & $\mathrm{X}$ & $\mathrm{X}$ & $\mathrm{X}$ & $\mathrm{X}$ & $\mathrm{X}$ & $\mathrm{X}$ & $1,7,15$ \\
\hline Cyclotrichium sp. $>44^{\mathrm{c}}$ & $\mathrm{X}$ & $\mathrm{X}$ & $\mathrm{X}$ & $\mathrm{X}$ & $\mathrm{X}$ & $\mathrm{X}$ & $\mathrm{X}$ & $\mathrm{X}$ & $\mathrm{X}$ & $\mathrm{X}$ & & & & 2,3 \\
\hline Nauplii $^{\mathrm{d}}$ & $\mathrm{X}$ & $\mathrm{X}^{\mathrm{b}}$ & $\mathrm{X}$ & $\mathrm{X}$ & $\mathrm{X}$ & $\mathrm{X}$ & $\mathrm{X}$ & $\mathrm{X}$ & $\mathrm{X}$ & $\mathrm{X}$ & $\mathrm{X}$ & & & 7,18 \\
\hline Heterotrophic dinoflagellates $>31$ & $\mathrm{X}$ & $\mathrm{X}$ & $\mathrm{X}$ & $\mathrm{X}$ & $\mathrm{X}$ & $\mathrm{X}$ & $\mathrm{X}$ & $\mathrm{X}$ & $\mathrm{X}$ & $\mathrm{X}$ & & & & $6,7-11,16,19,21$ \\
\hline Heterotrophic dinoflagellates $12-30$ & $\mathrm{X}$ & $\mathrm{X}$ & $\mathrm{X}$ & $\mathrm{X}$ & $\mathrm{X}$ & $\mathrm{X}$ & $\mathrm{X}$ & $\mathrm{X}$ & $\mathrm{X}$ & & & & & $6,7-11,16,19,21$ \\
\hline Rotifers $50-200$ & $\mathrm{X}$ & $\mathrm{X}$ & $\mathrm{X}$ & $\mathrm{X}$ & $\mathrm{X}$ & $\mathrm{X}$ & $\mathrm{X}$ & & & & & & & 6,7 \\
\hline Ebria tripartita $15-30^{\mathrm{e}}$ & $\mathrm{X}$ & & & $\mathrm{X}$ & & & & & & & & & & $4,16,22$ \\
\hline Ciliates $>31^{\mathrm{f}}$ & $\mathrm{X}$ & $\mathrm{X}$ & $\mathrm{X}$ & $\mathrm{X}$ & $\mathrm{X}$ & & & & & & & & & $2,6-8,12-14,17,20$ \\
\hline Ciliates $10-30^{g}$ & $\mathrm{X}$ & $\mathrm{X}$ & $\mathrm{X}$ & & & & & & & & & & & $2,6-8,13,14,17,20$ \\
\hline Heterotrophic flagellates ${ }^{\mathrm{h}}$ & & $\mathrm{X}$ & & & & & & & & & & & & 7,21 \\
\hline \multicolumn{15}{|c|}{ 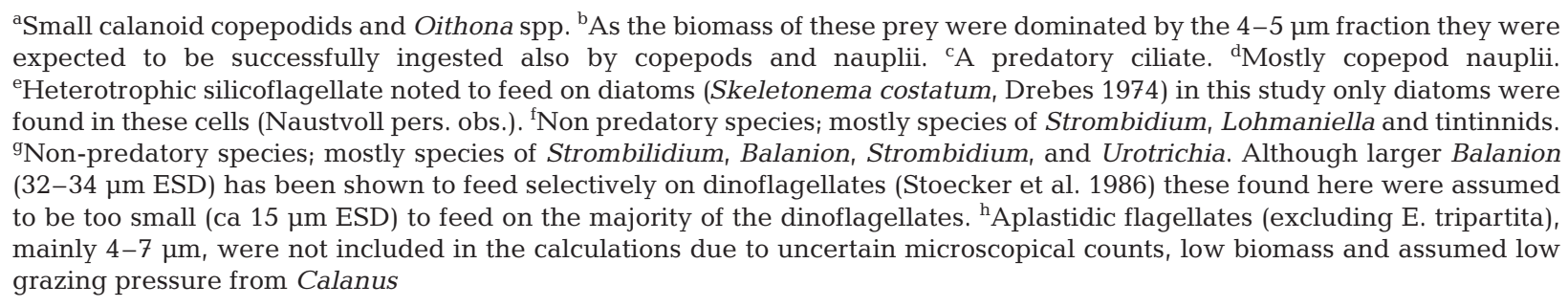 } \\
\hline \multicolumn{15}{|c|}{$\begin{array}{l}1 \text { (Atkinson 1994), } 2 \text { (Dolan 1991), } 3 \text { (Dolan \& Coats 1991), } 4 \text { (Drebes 1974), } 5 \text { (Gaines \& Elbrächter 1987), } 6 \text { (Godhantaraman } \\
\text { \& Krishnamurthy 1997), } 7 \text { (Hansen et al. 1994), } 8 \text { (Hansen 1991), } 9 \text { (Hansen \& Calado 1999), } 10 \text { (Jacobson \& Anderson 1986), } \\
11 \text { (Jeong 1994), } 12 \text { (Jonsson 1986), } 13 \text { (Kivi \& Setälä 1995), } 14 \text { (Montagnes 1996), } 15 \text { (Nakamura \& Turner 1997), } 16 \text { (Naustvoll } \\
\text { pers. obs.), } 17 \text { (Sime-Ngando et al. 1995), } 18 \text { (Stoecker \& Egloff 1987), } 19 \text { (Strom \& Buskey 1993), } 20 \text { (Tamigneaux et al. } 1997 \text { ), } \\
21 \text { (Tomas 1997), } 22 \text { (http://www.marbot.gu.se/SSS/Ebria_tripartita.htm) }\end{array}$} \\
\hline
\end{tabular}


Table 3. Microzooplankton grazing experiments. Specific algal growth rate $(\mu)$, microzooplankton grazing coefficient $(g)$, grazing impact (percentage of average standing stock removed $\mathrm{d}^{-1}$ ), body volume specific clearance $\left(\mathrm{C}_{\mathrm{bv}}\right.$ ), and body volume specific ingestion $\left(\mathrm{I}_{\mathrm{bv}}\right) . \mathrm{C}_{\mathrm{bv}}$ and $\mathrm{I}_{\mathrm{bv}}$ are based on total prey and grazer body volumes for the respective feeding guild (Table 2 ). I was not calculated for chl a due to uncertain conversion factor to algae volume. \pm SE for the mean. ${ }^{*} \mathrm{p}<0.05,{ }^{* *} \mathrm{p}<0.01$, and ${ }^{* * *} \mathrm{p}<0.001$ for $\mu$ or $g=0, \mathrm{n}=9$. Prey types are given with equivalent spherical diameter size ranges ( $\mu \mathrm{m})$. Dinoflagellates are only plastidic species. Only significant $g$-values $(\mathrm{p}<0.05)$ were used for corrections of copepod grazing rates

\begin{tabular}{|c|c|c|c|c|c|c|c|}
\hline Prey type & Expt & $r^{2}$ & $\begin{array}{c}\mu \\
\left(d^{-1}\right)\end{array}$ & $\begin{array}{c}g \\
\left(\mathrm{~d}^{-1}\right)\end{array}$ & $\begin{array}{l}\text { Grazing impact } \\
\quad\left(\% \mathrm{SS} \mathrm{d}^{-1}\right)\end{array}$ & $\begin{array}{c}\mathrm{C}_{\mathrm{bv}} \\
\left(10^{2} \mathrm{~d}^{-1}\right)\end{array}$ & $\begin{array}{c}\mathrm{I}_{\mathrm{bv}} \\
\left(\mathrm{d}^{-1}\right)\end{array}$ \\
\hline Chl a (>0.45) & $\begin{array}{l}96 a \\
96 b \\
96 c \\
96 d \\
97 a \\
97 b \\
97 c \\
98\end{array}$ & $\begin{array}{l}0.73 \\
0.80 \\
0.75 \\
0.90 \\
0.82 \\
0.96 \\
0.80 \\
0.59\end{array}$ & $\begin{array}{l}0.10 \pm 0.04 \\
0.15 \pm 0.05^{*} \\
0.58 \pm 0.07^{* * *} \\
0.79 \pm 0.07^{* * *} \\
0.48 \pm 0.05^{* * *} \\
0.75 \pm 0.05^{* * *} \\
0.32 \pm 0.06^{* *} \\
0.66 \pm 0.18^{* *}\end{array}$ & $\begin{array}{l}0.34 \pm 0.07^{* *} \\
0.47 \pm 0.08^{* * *} \\
0.55 \pm 0.11^{* *} \\
0.98 \pm 0.12^{* * *} \\
0.49 \pm 0.08^{* * *} \\
1.23 \pm 0.09^{* * *} \\
0.67 \pm 0.12^{* * *} \\
0.89 \pm 0.28^{*}\end{array}$ & $\begin{array}{l}29 \\
37 \\
42 \\
63 \\
39 \\
71 \\
49 \\
59\end{array}$ & $\begin{array}{r}8 \\
15 \\
4 \\
23 \\
5 \\
20 \\
14 \\
7\end{array}$ & \\
\hline Diatoms (8-15) & $\begin{array}{l}96 a \\
96 b \\
96 c \\
96 d\end{array}$ & $\begin{array}{l}0.71 \\
0.99 \\
0.01 \\
0.94\end{array}$ & $\begin{array}{r}1.10 \pm 0.12^{* * *} \\
1.23 \pm 0.03^{* * *} \\
-0.58 \pm 0.06^{* * *} \\
0.57 \pm 0.03^{* * *}\end{array}$ & $\begin{aligned} 0.84 & \pm 0.22^{* *} \\
1.12 & \pm 0.06^{* * *} \\
-0.03 & \pm 0.12 \\
0.47 & \pm 0.05^{* * *}\end{aligned}$ & $\begin{array}{l}57 \\
67 \\
37\end{array}$ & $\begin{array}{l}27 \\
49 \\
\\
11\end{array}$ & $\begin{array}{l}1 \\
3 \\
8\end{array}$ \\
\hline Diatoms (8-23) & $97 \mathrm{c}$ & 0.30 & $0.26 \pm 0.09^{*}$ & $0.27 \pm 0.16$ & 24 & 6 & 0.0 \\
\hline Diatoms (8-29) & $\begin{array}{l}97 a \\
97 b \\
98\end{array}$ & $\begin{array}{l}0.44 \\
0.24 \\
0.28\end{array}$ & $\begin{array}{l}0.50 \pm 0.13^{* *} \\
0.08 \pm 0.02^{* *} \\
1.70 \pm 0.29^{* * *}\end{array}$ & $\begin{array}{l}0.54 \pm 0.23^{*} \\
0.05 \pm 0.03 \\
0.74 \pm 0.45\end{array}$ & $\begin{array}{r}42 \\
5 \\
52\end{array}$ & $\begin{array}{r}6 \\
1 \\
15\end{array}$ & $\begin{array}{l}1.5 \\
0.2 \\
0.0\end{array}$ \\
\hline Flagellates (4-9) & $\begin{array}{l}96 a \\
96 b \\
96 c \\
96 d\end{array}$ & $\begin{array}{l}0.51 \\
0.98 \\
0.72 \\
0.45\end{array}$ & $\begin{array}{l}0.10 \pm 0.04 \\
0.86 \pm 0.03^{* * *} \\
0.43 \pm 0.04^{* * *} \\
0.05 \pm 0.08\end{array}$ & $\begin{array}{l}0.20 \pm 0.08^{*} \\
0.84 \pm 0.05^{* * *} \\
0.30 \pm 0.08^{* *} \\
0.34 \pm 0.15^{*}\end{array}$ & $\begin{array}{l}18 \\
57 \\
26 \\
29\end{array}$ & $\begin{array}{r}5 \\
29 \\
3 \\
13\end{array}$ & $\begin{array}{l}1.4 \\
5 \\
0.3 \\
3.8\end{array}$ \\
\hline Flagellates (5-10) & $\begin{array}{l}97 \mathrm{a} \\
97 \mathrm{~b} \\
97 \mathrm{c} \\
98\end{array}$ & $\begin{array}{l}0.12 \\
0.21 \\
0.00 \\
0.23\end{array}$ & $\begin{array}{l}1.18 \pm 0.10^{* * *} \\
0.32 \pm 0.03^{* * *} \\
0.19 \pm 0.13 \\
0.72 \pm 0.11^{* * *}\end{array}$ & $\begin{array}{l}0.16 \pm 0.16 \\
0.08 \pm 0.06 \\
0.04 \pm 0.24 \\
0.24 \pm 0.15\end{array}$ & $\begin{array}{r}15 \\
8 \\
4 \\
21\end{array}$ & $\begin{array}{l}2 \\
1 \\
1 \\
5\end{array}$ & $\begin{array}{l}0.0 \\
0.0 \\
0.0 \\
0.3\end{array}$ \\
\hline Flagellates (10-18) & $\begin{array}{l}96 a \\
96 b \\
96 c \\
96 d\end{array}$ & $\begin{array}{l}0.01 \\
0.95 \\
0.31 \\
0.00\end{array}$ & $\begin{array}{l}0.28 \pm 0.17 \\
1.30 \pm 0.07^{* * *} \\
0.68 \pm 0.10^{* * *} \\
0.00 \pm 0.07\end{array}$ & $\begin{array}{l}0.06 \pm 0.31 \\
1.34 \pm 0.13^{* * *} \\
0.31 \pm 0.19 \\
0.02 \pm 0.14\end{array}$ & $\begin{array}{r}6 \\
74 \\
26 \\
2\end{array}$ & $\begin{array}{r}3 \\
64 \\
3 \\
1\end{array}$ & $\begin{array}{l}0.6 \\
8 \\
0.3 \\
0.1\end{array}$ \\
\hline Flagellates (14-21) & 98 & 0.01 & $1.35 \pm 0.16^{* * *}$ & $0.07 \pm 0.24$ & 7 & 1 & 0.1 \\
\hline Dinoflagellates (12-20) & $\begin{array}{l}96 \mathrm{a} \\
96 \mathrm{~b} \\
96 \mathrm{c} \\
96 \mathrm{~d}\end{array}$ & $\begin{array}{l}0.03 \\
0.91 \\
0.81 \\
0.50\end{array}$ & $\begin{array}{l}0.36 \pm 0.09^{* *} \\
1.44 \pm 0.09^{* * *} \\
0.34 \pm 0.07^{* *} \\
0.75 \pm 0.16^{* *}\end{array}$ & $\begin{array}{l}0.08 \pm 0.17 \\
1.24 \pm 0.16^{* * *} \\
0.64 \pm 0.13^{* *} \\
0.72 \pm 0.29^{*}\end{array}$ & $\begin{array}{r}7 \\
71 \\
47 \\
51\end{array}$ & $\begin{array}{r}3 \\
59 \\
6 \\
25\end{array}$ & $\begin{array}{l}0.1 \\
0.3 \\
0.4 \\
0.1\end{array}$ \\
\hline Dinoflagellates (10-29) & $\begin{array}{l}97 \mathrm{c} \\
98\end{array}$ & $\begin{array}{l}0.34 \\
0.67\end{array}$ & $\begin{array}{l}0.23 \pm 0.07^{* *} \\
0.66 \pm 0.24^{*}\end{array}$ & $\begin{array}{l}0.22 \pm 0.12 \\
1.37 \pm 0.36^{* *}\end{array}$ & $\begin{array}{l}20 \\
75\end{array}$ & $\begin{array}{r}5 \\
28\end{array}$ & $\begin{array}{l}0.1 \\
0.1\end{array}$ \\
\hline Dinoflagellates (22-42) & $\begin{array}{l}97 \mathrm{a} \\
97 \mathrm{~b}\end{array}$ & $\begin{array}{l}0.01 \\
0.08\end{array}$ & $\begin{array}{l}0.10 \pm 0.26 \\
0.48 \pm 0.06^{* * *}\end{array}$ & $\begin{array}{l}0.11 \pm 0.45 \\
0.08 \pm 0.10\end{array}$ & $\begin{array}{r}11 \\
7\end{array}$ & $\begin{array}{l}4 \\
3\end{array}$ & $\begin{array}{l}0.6 \\
0.2\end{array}$ \\
\hline Myrinecta rubra (21-46) & $\begin{array}{l}97 \mathrm{a} \\
97 \mathrm{~b} \\
98\end{array}$ & $\begin{array}{l}0.06 \\
0.00 \\
0.51\end{array}$ & $\begin{array}{l}1.04 \pm 0.15^{* * *} \\
0.85 \pm 0.25^{*} \\
0.35 \pm 0.07^{* *}\end{array}$ & $\begin{array}{l}0.16 \pm 0.25 \\
0.04 \pm 0.36 \\
0.26 \pm 0.11^{*}\end{array}$ & $\begin{array}{r}15 \\
4 \\
23\end{array}$ & $\begin{array}{r}3 \\
1 \\
41\end{array}$ & $\begin{array}{l}0.0 \\
0.0 \\
0.0\end{array}$ \\
\hline
\end{tabular}

concentration; and (3) microzooplankton grazing rates are proportional to body carbon for all microzooplankton species, for each prey type in each experiment. For equations and further description of the Guild method see Nejstgaard et al. (1997).

The general method: The Guild method is rather complex (see 'Results and discussion'). Therefore we present and evaluate a simplified version of the method that does not include the use of guild tables.
Instead it assumes that the underestimation of microzooplankton grazing for each prey type is proportional to the measured microzooplankton community grazing rate on this prey and the total loss of microzooplankton community biomass in the copepod bottle.

In this method the copepod grazing rates were corrected for each prey type $(p)$, according to Eq. (1):

$$
g_{\text {corr }, p}=g_{\text {cop }, p}+k_{p}
$$


where $g_{\mathrm{corr}, p}$ is the corrected copepod grazing coefficient $\left(\mathrm{d}^{-1}\right)$ for prey type $p, g_{\mathrm{cop}, p}$ is the uncorrected copepod grazing coefficient for prey type $p$ according to Frost (1972), and $k_{p}$ is the correction for loss of microzooplankton grazing on prey type $p$ in the copepod bottle. $k_{p}$ is calculated according to Eqs (2) to (4):

$$
\begin{gathered}
k_{p}=g_{\text {mic }, p}\left(\frac{\bar{C}-\bar{C}^{*}}{\bar{C}}\right) \\
\bar{C}=\left(c_{t}-c_{0}\right) \ln \left(C_{t} / C_{0}\right)^{-1} \\
\bar{C}^{*}=\left(c_{t}^{*}-C_{0}\right) \ln \left(C_{t}^{*} / C_{0}\right)^{-1}
\end{gathered}
$$

where $g_{\text {mic, } p}$ is the microzooplankton grazing coefficient for prey type $p\left(\mathrm{~d}^{-1}\right.$, obtained from simultaneously performed dilution experiments), while $\bar{C}$ and $\bar{C}^{*}$ is the average concentration of all microzooplankton $\left(\mu \mathrm{g} \mathrm{C}^{-1}\right.$ ) in the control and copepod bottle $\left({ }^{*}\right)$ respectively, $c_{0}$ is the concentrations of all microzooplankton at the start of the incubation, while $c_{t}$ and $C_{t}{ }^{*}$ are the concentrations of all microzooplankton at the end of the incubation in the control (average for all controls) and the copepod bottle $\left({ }^{*}\right)$, respectively.

Because this correction method is based on the general loss of microzooplankton biomass in the grazing bottles, rather than specific feeding guilds, and because it makes a more general use of the method possible (see 'Discussion'), we will refer to this method as the 'general' correction method hereafter.

Other calculations and statistical analysis. Copepod prey preference was calculated as Manly's (1974) index for variable prey populations, normalized for copepod concentration as described in Nejstgaard et al. (1997). StatView5 (SAS Institute Inc., Cary, NC) was used for basic statistics, ANOVA and post hoc tests. Multiple comparisons among groups were tested using either Scheffé's multiple contrasts (Zar 1996, p. 222-225), or if $n \geq 6$, the post hoc test described by Games \& Howell (1976). Regressions were compared for differences using the Chow-test (Koutsoyiannis 1977).

\section{RESULTS AND DISCUSSION}

\section{Microzooplankton grazing}

The microzooplankton community showed a significant grazing impact on the phytoplankton, with grazing rates often surpassing the estimated specific phytoplankton growth rates (Table 3). The microzooplankton consumed 29 to $71 \%$ of the chl a standing stocks (SS) $\mathrm{d}^{-1}$ (Table 3). Thus the phytoplankton appear to be controlled by microzooplankton grazing, as is often the case in the field, at least during the warmer seasons (Nielsen \& Kiørboe 1994, Banse 1995, Putland 2000).

The cell counts indicated that the diatoms and some of the flagellates were exposed to the highest microzooplankton grazing pressure, although not all of these rates were statistically significant (Table 3). We argue that the increased errors associated with fixation, microscopic analysis and limited numbers of some protists may explain the lack of statistical significance ( $p>$ 0.05 ) in some cases of high grazing rates based on cell counts, compared to the chl a analysis (cf. Båmstedt et al. 2000). The fact that all grazing rates $>0.16 \mathrm{~d}^{-1}$ based on cell counts had p values $<0.15$ (not shown), and that the estimated microzooplankton grazing impact were within the same range for cell counts and chl a analysis (Table 3), supports this argument.

The microzooplankton body volume specific ingestion rates $\left(\mathrm{I}_{\mathrm{bv}}=0\right.$ to $8 \mathrm{~d}^{-1}$, Table 3 ) were only occasionally high and were always within published maximum values (Hansen et al. 1997); microzooplankton body volume specific clearance rates $\left(\mathrm{C}_{\mathrm{bv}}=0\right.$ to $64 \times 10^{2} \mathrm{~d}^{-1}$, Table 3) were at least 2 orders of magnitude below reported maximum values (Hansen et al. 1997). Thus, we conclude that microzooplankton grazing rates based on cell counts were most likely conservative estimates. Nevertheless, as a precautionary measure only the copepod grazing rates corresponding to a significant $(p<0.05)$ microzooplankton grazing value were corrected.

\section{Selective copepod predation on microzooplankton and decrease of prey in the bottles}

The females and copepodites of Calanus finmarchicus and C. helgolandicus always showed the highest clearance rates (up to $0.5 \mathrm{l} \mathrm{cop}^{-1} \mathrm{~d}^{-1}$ ) and prey preference (Manly's alpha generally $>12.5$ ) for rotifers and ciliates $>30 \mu \mathrm{m}$, regardless of whether or not grazing rates were corrected (Tables $4 \& 5$ ). This is in accordance with similar previous experiments (Nejstgaard et al. 1994, 1997) and other literature for late stages of Calanus from coastal waters (Fessenden \& Cowles 1994, Ohman \& Runge 1994).

The sum of all ciliates and metazoa made up only 2 to $30 \%$ of the available prey $\mathrm{C}$ but contributed to $17-93 \%$ of uncorrected, and 13 to $59 \%$ of corrected C ingestion rates, despite the presence of alternative algal prey, sometimes in very high concentrations. The copepods also ingested significant amounts of heterotrophic flagellates. Thus the copepod predation led to a substantial decrease in the biomass of the preferred prey items: rotifers, other mesozooplankton and ciliates $>30 \mu \mathrm{m}$ (37 to $93 \%$, average $63 \%$, Table 6 ). 


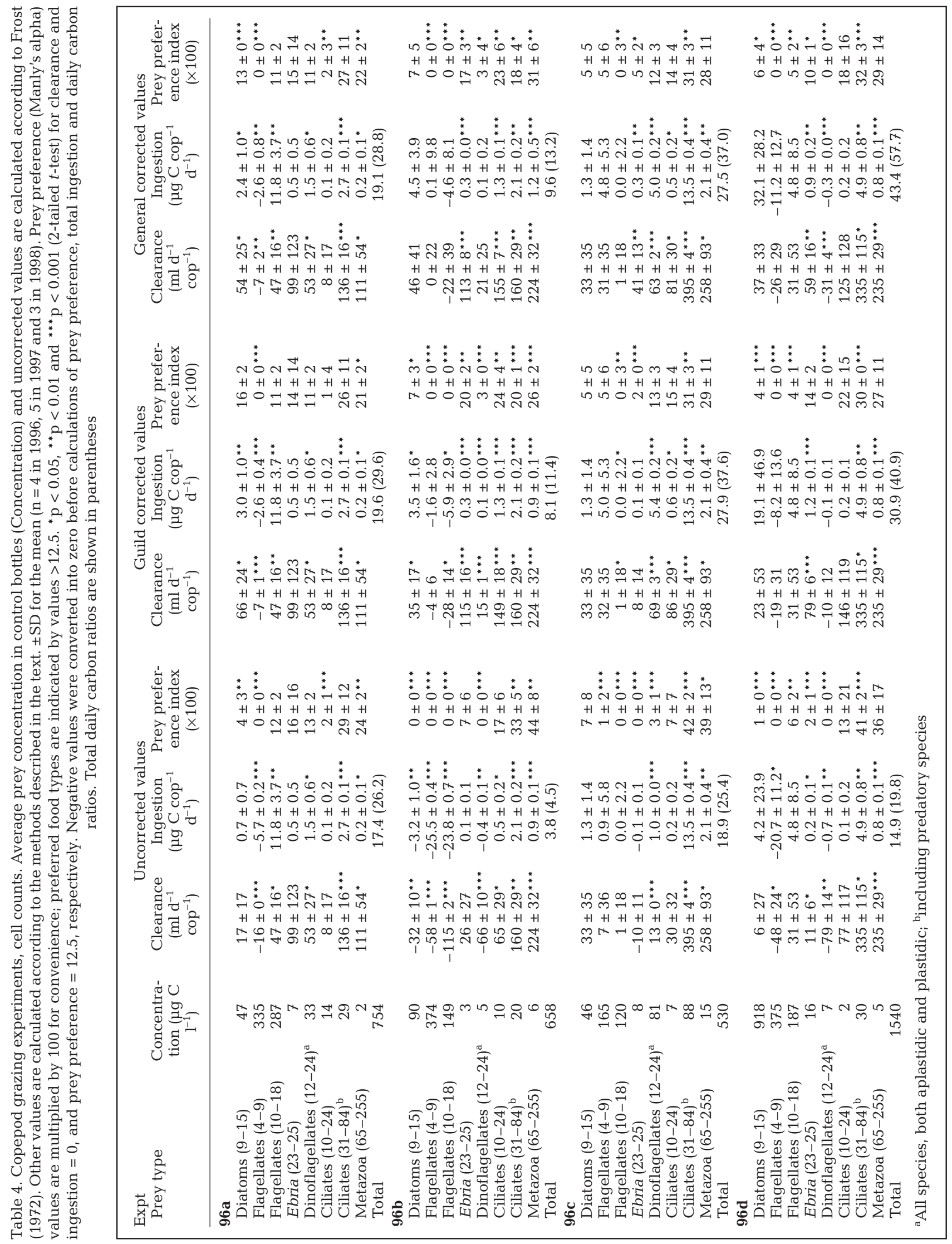




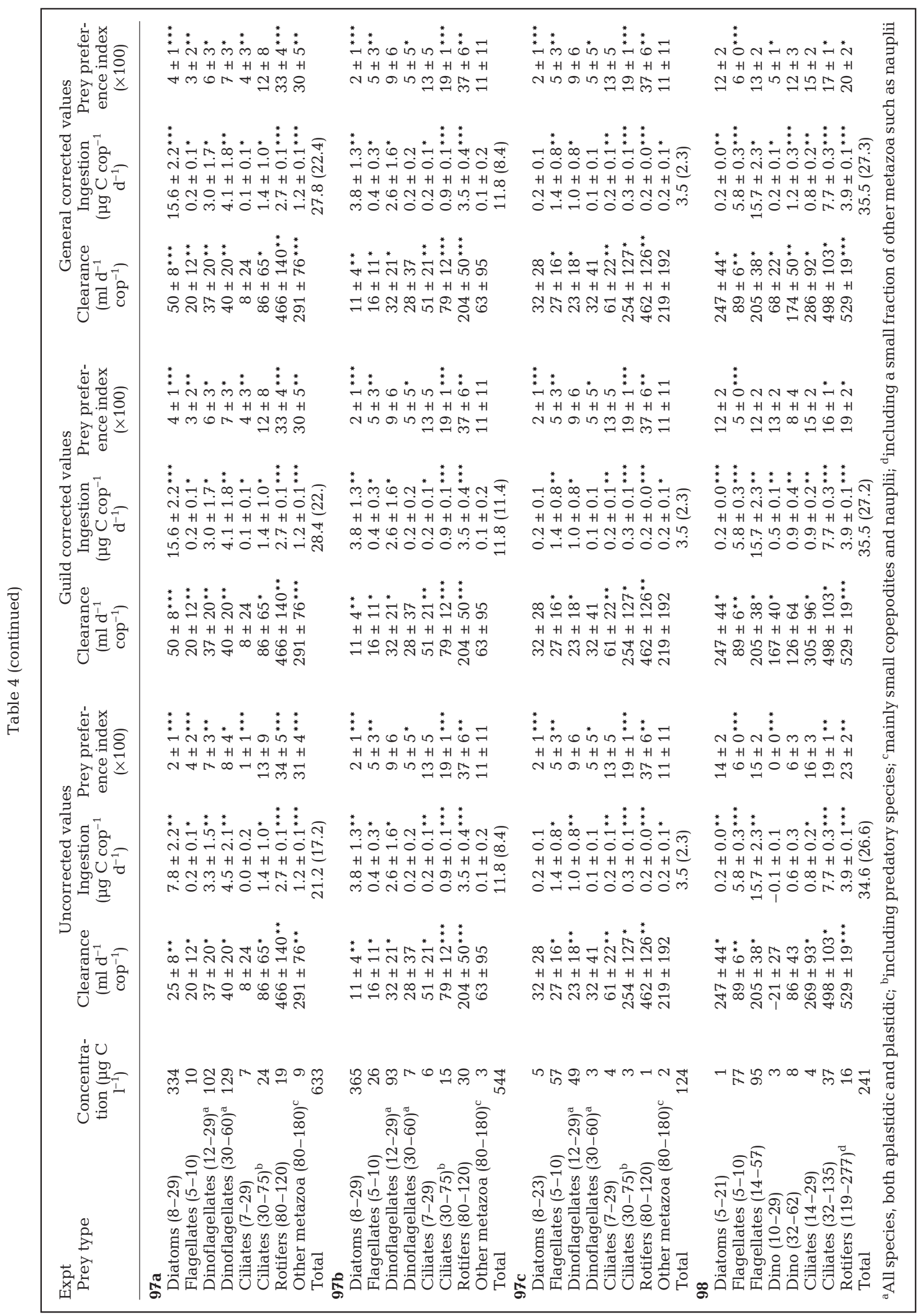


Table 5. Copepod grazing experiments, chl a $>0.45 \mu \mathrm{m}$. As all microzooplankton are assumed to feed on chl $a$, there is no difference between Guild and General correction methods. Otherwise as Table 4

\begin{tabular}{|c|c|c|c|c|c|}
\hline \multirow[t]{2}{*}{ Expt } & \multirow{2}{*}{$\begin{array}{c}\text { Chl a } \\
\text { concentration } \\
\left(\mu \mathrm{g} \mathrm{l}^{-1}\right)\end{array}$} & \multicolumn{2}{|c|}{ Uncorrected values } & \multicolumn{2}{|c|}{ Corrected values } \\
\hline & & $\begin{array}{c}\text { Clearance } \\
\left(\mathrm{ml} \mathrm{d}^{-1} \mathrm{cop}^{-1}\right)\end{array}$ & $\begin{array}{c}\text { Ingestion } \\
(\mu \mathrm{g} \mathrm{chl} \mathrm{a} \\
\left.\operatorname{cop}^{-1} \mathrm{~d}^{-1}\right)\end{array}$ & $\begin{array}{c}\text { Clearance } \\
\left(\mathrm{ml} \mathrm{d}^{-1} \mathrm{cop}^{-1}\right)\end{array}$ & $\begin{array}{c}\text { Ingestion } \\
(\mu \mathrm{g} \mathrm{chl} \mathrm{a} \\
\left.\operatorname{cop}^{-1} \mathrm{~d}^{-1}\right)\end{array}$ \\
\hline $96 a$ & 4.2 & $-2 \pm 9$ & $-0.01 \pm 0.04$ & $13 \pm 8^{*}$ & $0.05 \pm 0.03^{*}$ \\
\hline $96 b$ & 5.1 & $8 \pm 32$ & $0.03 \pm 0.15$ & $42 \pm 37$ & $0.20 \pm 0.16$ \\
\hline $96 \mathrm{c}$ & 6.1 & $4 \pm 6$ & $0.02 \pm 0.03$ & $47 \pm 6^{* * *}$ & $0.28 \pm 0.03^{* * *}$ \\
\hline $96 d$ & 10.4 & $22 \pm 3^{* * *}$ & $0.22 \pm 0.02^{* * *}$ & $89 \pm 11^{* * *}$ & $0.87 \pm 0.11^{* * *}$ \\
\hline $97 a$ & 18.5 & $19 \pm 3^{* * *}$ & $0.33 \pm 0.05^{* * *}$ & $40 \pm 5^{* * *}$ & $0.68 \pm 0.08^{* * *}$ \\
\hline $97 \mathrm{~b}$ & 13.9 & $-40 \pm 19^{* *}$ & $-0.64 \pm 0.32^{*}$ & $15 \pm 18$ & $0.31 \pm 0.17^{*}$ \\
\hline $97 \mathrm{C}$ & 6.2 & $35 \pm 14^{* *}$ & $0.20 \pm 0.08^{* *}$ & $48 \pm 9^{* * *}$ & $0.28 \pm 0.03^{* * *}$ \\
\hline 98 & 0.8 & $105 \pm 92$ & $0.07 \pm 0.06$ & $163 \pm 86$ & $0.11 \pm 0.05^{*}$ \\
\hline
\end{tabular}

Table 6. Percentage loss of prey $\mathrm{C}$ and chl a in copepod incubation bottles relative to blank bottles. Metazoa are totally dominated by rotifers in the 1997 and 1998 experiments

\begin{tabular}{|c|c|c|c|c|c|c|}
\hline Expt & Chl $a$ & $\begin{array}{c}\text { All } \\
\text { prey C }\end{array}$ & $\begin{array}{c}\text { All } \\
\text { autotroph C }\end{array}$ & $\begin{array}{c}\text { Metazoa or } \\
\text { rotifer C }\end{array}$ & $\begin{array}{l}\text { Ciliates } \\
>30 \mu \mathrm{m} \mathrm{C}\end{array}$ & $\begin{array}{l}\text { Other micro- } \\
\text { zooplankton C }\end{array}$ \\
\hline $96 a$ & -1 & 10 & 7 & 44 & 51 & 17 \\
\hline $96 b$ & 3 & -41 & -46 & 68 & 57 & 9 \\
\hline $96 \mathrm{c}$ & 2 & 22 & 3 & 72 & 86 & 5 \\
\hline $96 d$ & 10 & -1 & -3 & 68 & 80 & 8 \\
\hline $97 a$ & 11 & 21 & 17 & 93 & 38 & 12 \\
\hline $97 b$ & -28 & 13 & 9 & 69 & 37 & 15 \\
\hline $97 \mathrm{C}$ & 18 & 17 & 12 & 91 & 71 & 13 \\
\hline 98 & 28 & 49 & 31 & 84 & 81 & 34 \\
\hline Average & 6 & 11 & 4 & 74 & 63 & 14 \\
\hline
\end{tabular}

Note however that the chl $a$ and the majority of the potential prey biomass $\mathrm{C}$ decreased on average by only 4 to $14 \%$, compared to the control bottles (Table 6). This is much less than the 30 to $40 \%$ decrease in prey abundance needed to yield statistically significant cell counts compared to control bottles in traditional uncorrected incubation experiments (Gifford 1993, Båmstedt et al. 2000).

\section{Negative uncorrected copepod grazing rates}

A number of statistically significant $(p<0.05)$ negative clearance and ingestion rates were obtained from the uncorrected cell counts and chl a data (Tables 4 $\& 5)$. As negative rates per se are not possible, this strongly suggests a methodological bias in the uncorrected data. This could either be due to release of nutrients by the copepods favouring algal growth under nutrient-stressed conditions (Lehman 1980, Roman \& Rublee 1980), and/or to grazing interactions between the microzooplankton and the copepods releasing the overall grazing pressure on the phytoplankton in the experimental bottles. In order to avoid the first problem, nutrients should be added when nutrient limitation is anticipated to become a problem (Roman \& Rublee 1980, Landry 1993).

\section{Nutrient limitation?}

Initial nutrient concentrations in the incubation bottles are shown in Table 1. Unfortunately nutrients were not re-sampled when the incubations were terminated. However, the nutrients were measured in the mesocosms after the incubations were terminated, but before the mesocoms were re-fertilized (Table 1). If we assume that the average light and nutrient environments were similar in the incubation bottles and the upper layers of the respective mesocosm (cf. 'Material and methods'), we may assume that the nutrients were depleted at comparable rates in these environments. Then nitrate and phosphate would not appear to be limiting in most experiments, perhaps with the exception of $97 \mathrm{a}, \mathrm{b}$. However $97 \mathrm{a}, \mathrm{b}$ received extra nutrients (Table 1) and may not be directly compared in this way. The other experiments would probably not have been significantly nutrient limited 
unless depletion rates were at least twice as high as in the mesocosms.

Alternatively, nutrient depletion rates in the control bottles may be estimated if we assume: (1) that the total accumulation of particulate (POC) and dissolved organic material (DOC) equals inorganic nutrients removed from the water in a Redfield atomic ratio (106 C : 16 N : 1 P, Falkowski 2000); and (2) that the total POC and DOC accumulation is $3 \times$ the measured net accumulation of total phyto- and zooplankton (cf. Banse 1974, Bronk \& Ward 2000). If so, the phytoplankton would again only have become N-limited in Expt $97 \mathrm{~b}$ (Table 1). Nitrate appeared to be potentially more limiting than phosphate, but none of these would probably be limiting in the other experiments.

Zooplankton grazing may decrease silicate concentrations (Sommer 1988). Silicate could have been limiting in the 96a and 96c experiments (Table 1). However, a negative uncorrected copepod grazing rate for diatoms was only found in 1 experiment with high silicate concentrations (96b). Instead a number of silicateindependent prey showed negative uncorrected copepod grazing rates in Expts 96a and c (Table 4). Thus, it is very unlikely that silicate limitation may have contributed to the negative uncorrected copepod grazing rates.

Copepod nutrient regeneration effects are complex. Copepods regenerate $\mathrm{N}$ in reduced forms, which may be more readily assimilated by the phytoplankton, but copepod predation on the microzooplankton may to some extent also control the ammonium regeneration (Glibert 1998). Note that microzooplankton grazing rates were high (Table 3), indicating high nutrient regeneration rates. Presence of reduced inorganic N sources at the start of the incubations would decrease the risk of nutrient limitation (not measured). Also, algal growth may show signs of significant external pools even at near-zero analytical values of dissolved nutrients (Andersen et al. 1991).

Nevertheless, if negative uncorrected copepod grazing rates were mainly caused by nutrient regeneration, we would expect uncorrected copepod grazing rates (Tables 4 \& 5) to be correlated to terminal nutrient concentrations, and/or copepod concentrations (Table 1). However, no such correlation was found $\left(\mathrm{r}^{2}<0.06\right.$, $\mathrm{p}=0.12$ to 0.8 , not shown). Thus we conclude that the main factor causing negative uncorrected copepod grazing rates was not nutrient limitation.

\section{Microzooplankton-copepod grazing interactions, evaluation of effects and corrections}

Uncorrected instantaneous copepod grazing rates showed highly significant correlations $(p \leq 0.006)$ to

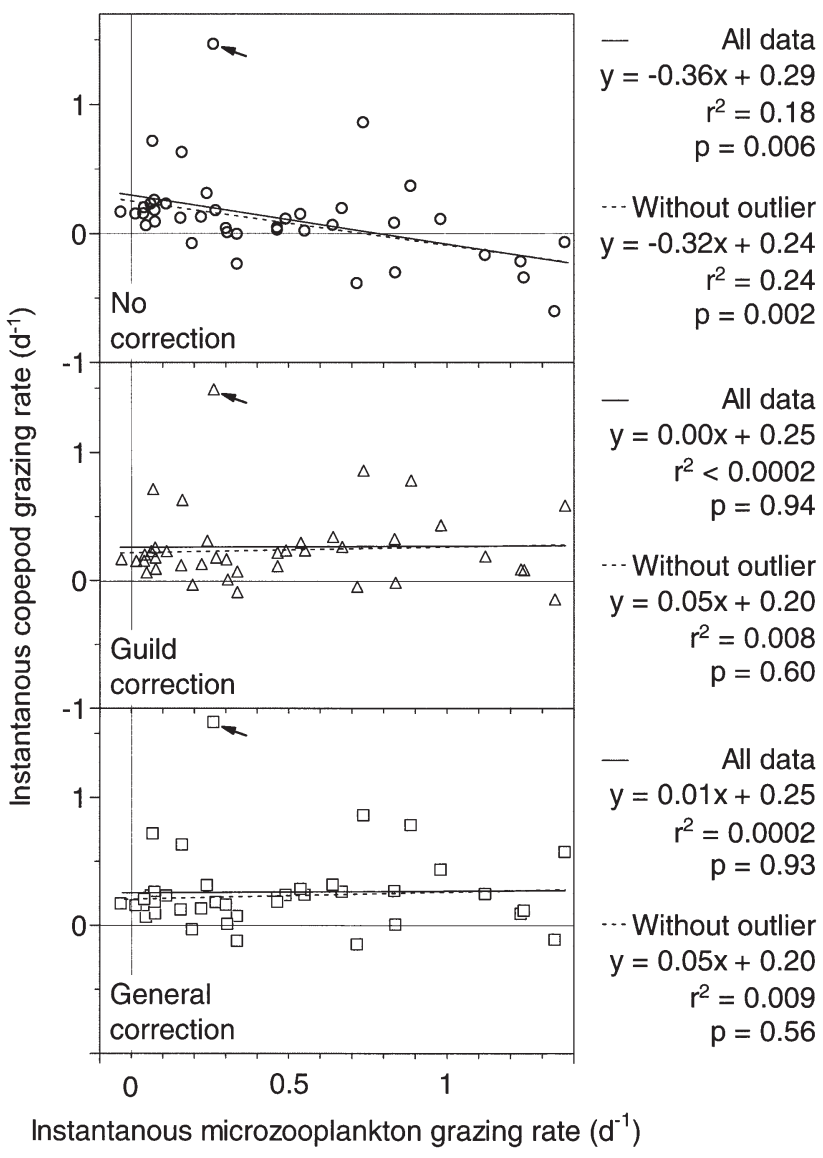

Fig. 1. Correlation between instantaneous microzooplankton and Calanus spp. grazing rates using either No, Guild, or General correction of the copepod grazing rates. Only autrophic food items for which microzooplankton grazing rates were measured are included. Flagellates $<10 \mu \mathrm{m}$ most likely contain some heterotrophic species. Regressions for all data ( $\mathrm{n}=46$, solid lines), and with outlier (arrow) removed ( $\mathrm{n}=45$, hatched lines); see text for comments

instantaneous microzooplankton grazing rates, regardless of whether or not the outlier was removed (Fig. 1). The outlier was a case of large $(>32 \mu \mathrm{m})$ autotrophic ciliates (Mesodinum rubrum) occurring in high enough concentrations to be determined separately in the dilution experiments (Expt 98, Table 3). This outlier is most likely a result of strongly selective copepod feeding comparable to the other large ciliates (Experiment 98, Table 4). In contrast, corrected copepod grazing rates were not correlated to microzooplankton grazing rates, irrespective of whether or not the outlier was removed ( $\mathrm{p}=0.56$ to 0.94 , Fig. 1 ). This clearly suggests that food-web grazing interactions had a strong impact on the uncorrected copepod grazing rates that increased with microzooplankton community grazing pressure in the food suspension. But this bias was successfully corrected by both methods (Fig. 1). 


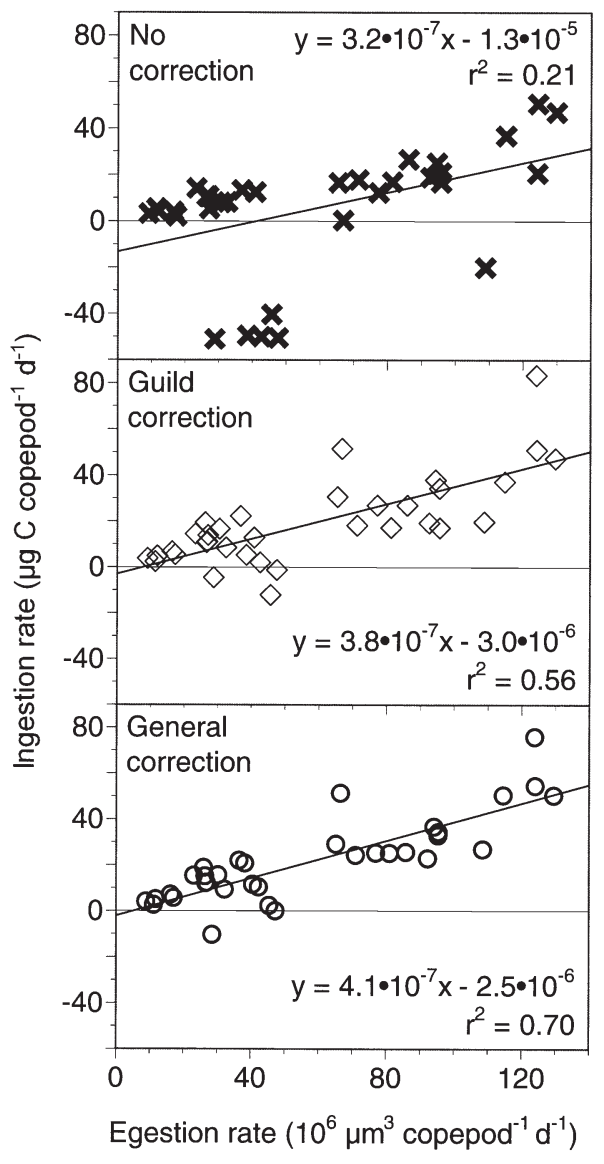

Fig. 2. Calanus spp. copepodites V and females. Relationship between volumetric egestion and ingestion rates, using either No, Guild, or General correction of the copepod ingestion rates $(n=34)$. The uncorrected regression showed 6 outliers below zero ingestion rates; see text for comments

Volumetric egestion rates, used as an independent measure of copepod feeding activity, showed strong linear correlations to corrected copepod ingestion rates $\left(\mathrm{r}^{2}=\right.$ 0.56 to $0.70, \mathrm{p}<0.0001$ ), with $y$-axis intercepts that were not significantly different from zero $(p>0.46$ to 0.47 , Fig. 2). These data, especially from flagellate-dominated blooms (discussed below), also showed a striking similarity to ingestion-egestion data for Calanus finmarchicus stage CV feeding on monocultures of the naked flagellate Rhodomonas baltica recalculated from Båmstedt et al. (1999) (Fig. 3). As there are no food-web interactions in the monoculture data, this suggests that corrected copepod grazing rates apparently yield a very close estimate of the in vitro feeding rates.

The uncorrected copepod ingestion rates showed 6 clearly negative outliers in Fig. 2. These outliers were all obtained from experiments where high microzooplankton grazing rates coincided with high copepod predation on the microzooplankton. However, the outliers were successfully corrected (compare the lower panels). Because of the outliers, the uncorrected grazing data did not satisfy the criteria for a statistical analysis of the linear regression, but it indicated a substantial negative $y$-axis intercept in contrast to corrected (Fig. 2) and unbiased data (Fig. 3).

Corrected daily C rations were on average ca $30 \%$ (range 16 to $52 \%$, Table 4), which is close to the upper range of Calanus spp. ingestion rates in the literature (Hansen et al. 1997). This was expected because plankton concentrations were above the critical food

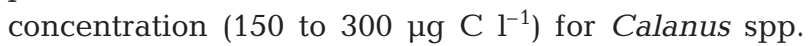
(Frost 1972, Gamble 1978), and were comparable to dense blooms in Scandinavian fjords and the North Sea (e.g. Braarud et al. 1958, Gamble 1978, Paasche \& Østergren 1980, Andersen \& Sørensen 1986, Heimdal \& Reisegg 1996). Uncorrected rates averaged only $19 \%$ (range 5 to $34 \%$, Table 4 ).

Also, corrected copepod clearance of prey $<10 \mu \mathrm{m}$ were low (Table 4), which is in accordance with the literature (e.g. Frost 1972, Nejstgaard et al. 1995, Hansen et al. 1997). This suggests that corrected rates yield precise estimates, and not maximum estimates as previously suggested for the Guild method (Perez et al. 1997).

\section{Comparison between guild and general corrected results}

The Guild and General methods occasionally yielded somewhat different results (e.g. Expt 96d, Table 4), but in most cases the results were very similar (Table 4 ,

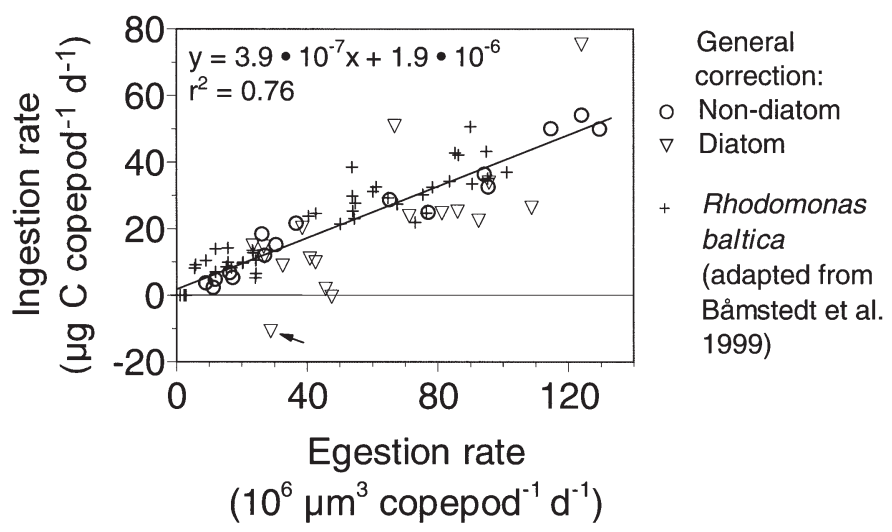

Fig. 3. Calanus spp. copepodites V and females. Relationship between ingestion rate and faecal volume production. Results from Expts 96a to 98 ( $O$ and $\nabla$ ) based on the General correction (Fig. 2), compared to results from laboratory experiments $(+)$ with C. finmarchicus feeding on monospecific laboratory cultures of the cryptophyte Rhodomonas baltica (adapted from Båmstedt et al. 1999). Non-diatom food suspensions $(\nabla)$ were dominated by flagellates, including dinoflagellates, of different size and taxa in the different experiments. Equation including all data except outlier, $n=77$. Arrow denotes outlier; see text for further comments and equations 
Figs $1 \& 2$, no significant differences between the regressions, $\mathrm{p} \gg$ 0.50, Chow-test).

The goal with the Guild correction method was to achieve precise corrections of copepod grazing rates in natural plankton (Nejstgaard et al. 1997). But this method is rather complex. In order to increase the applicability of the method we therefore omitted the use of different feeding guilds in the general method. This may theoretically lower the precision of the corrections. For instance, if both the copepod and its prey were highly selective feeders, and the selected microzooplankton made up only a fraction of the total microzooplankton, then the general method would tend to result in insufficient corrections. However, this would not be expected in our data, despite selective feeding by the copepods (cf. Table 6), because the selected microzooplankton were assumed to ingest a wide range of prey types (Table 2). Note also that the food medium was pre-screened to remove mesozooplankton. If this had not been done, copepods could also have fed upon carnivorous mesozooplankton. Then a more complex method may have been needed to resolve the feeding interactions.

On the other hand, the omission of feeding guilds may reduce sources of error associated both with assigning proper feeding guilds, and the taxonomical accuracy needed when analysing samples. It may also be argued that since both correction methods are based on the same microzooplankton community grazing rates there should be little difference between them. However, the total microzooplankton community grazing rate is a sum of all the individual rates. If the different microzooplankters were highly selective feeders, the rates calculated for each prey item would stem only from a fraction of the total microzooplankton community. Then, the Guild method would tend to yield a better (higher) estimate than the general method.

Reducing the complexity of the sample analysis in the General method also makes it suitable for computer-automated analysis. Computer analysis may handle pigment content and cell sizes properly, but typically not taxonomy (cf. Verity \& Paffenhöfer 1996). Because the General method does not require manual microscopy (except for determination of the dominant taxa in each experiment) it should be ideal to combine with automated image analysis or flow-cytometric sample treatment in future grazing studies.

\section{Faecal pellet production as a simple measure of total feeding rate}

Volumetric egestion rates were strongly correlated to corrected ingestion rates (Fig. 2), and matched pre- viously published unbiased ingestion-egestion data for Calanus spp. (Båmstedt et al. 1999) (Fig. 3). In particular, the data from non-diatom food suspensions $(y=$ $\left.3.9 \times 10^{-7} X+1.0 \times 10^{-6}, \mathrm{r}^{2}=0.95, \mathrm{p}=10^{-10}, \mathrm{n}=16\right)$ closely matched ( $\mathrm{p}>0.4$, Chow test) the regression for Rhodomonas baltica $\left(y=4.0 \times 10^{-7} \mathrm{x}+3.0 \times 10^{-6}, \mathrm{r}^{2}=\right.$ 0.87, $\left.\mathrm{p}=10^{-20}, \mathrm{n}=45\right)\left(\mu \mathrm{gC} \mu \mathrm{m}^{-3}\right.$, Fig. 3). The combined equation for all non-diatom dominated data showed a very strong correlation $\left(y=3.9 \times 10^{-7} X+\right.$ $2.7 \times 10^{-6}, \mathrm{r}^{2}=0.89$, slope $\mathrm{p}=10^{-30}$, intercept $\mathrm{p}=0.01$, $\mathrm{n}=61$ ), and should thus give the best estimates of total ingestion rates for late copepodites of Calanus spp. feeding on various natural non-diatom dominated diets.

The regression from diatom food suspensions showed larger variations in the data (Fig. 3), and was not significantly different from non-diatom data ( $\mathrm{p} \gg$ 0.5, Chow-test), neither with nor without the outlier. However, the regression for Rhodomonas baltica was slightly different ( $p=0.05$, Chow-test) from the combined diatom and non-diatom regression. But with the outlier removed, the regression of the combined data $\left(y=3.9 \times 10^{-7} x+1.8 \times 10^{-6}, r^{2}=0.70\right)$ was not significantly different from the $R$. baltica regression $(\mathrm{p}>0.1$, Chow-test). Thus all values (except the negative outlier) could be plotted as one regression $\left(y=3.9 \times 10^{-7} X\right.$ $+1.9 \times 10^{-6}, \mathrm{r}^{2}=0.76$, slope $\mathrm{p} \ll 0001$, intercept $\mathrm{p}=$ $0.21, \mathrm{n}=77$ ), which may be used to estimate ingestion rates for Calanus spp. in natural food suspensions, including diatoms.

Faecal pellet numbers were also correlated to corrected ingestion rates, and were similar to previously published values for Calanus spp. (Fig. 4). However, pellet numbers show larger variation around the regression than pellet volume. This is expected from the literature because pellet number, size and density may all vary with feeding rates, as well as type, size and physiological status of both the predator and prey (e.g. Marshall \& Orr 1955, Gaudy 1974, Ayukai \& Nishizawa 1986, Urban et al. 1993, Butler \& Dam 1994, Feinberg \& Dam 1998, Båmstedt et al. 1999, and references therein).

There are also potential problems with pellet reworking by the copepods (Noji et al. 1991), disruption of pellets due to bottle agitation, loss and breakage during sampling (J.C.N. pers. obs). We believe that disruption, loss and measurement errors may explain a substantial part of the variation in previously published data (cf. the large size variation in fragile coccolith filled Calanus pellets, Harris 1994). However, these errors may be minimised by avoiding zooplankton specialised in pellet feeding, such as Oithona spp. (cf. González et al. 2000), use of egg production chambers with false mesh bottoms preventing contact between mesozooplankton and pel- 


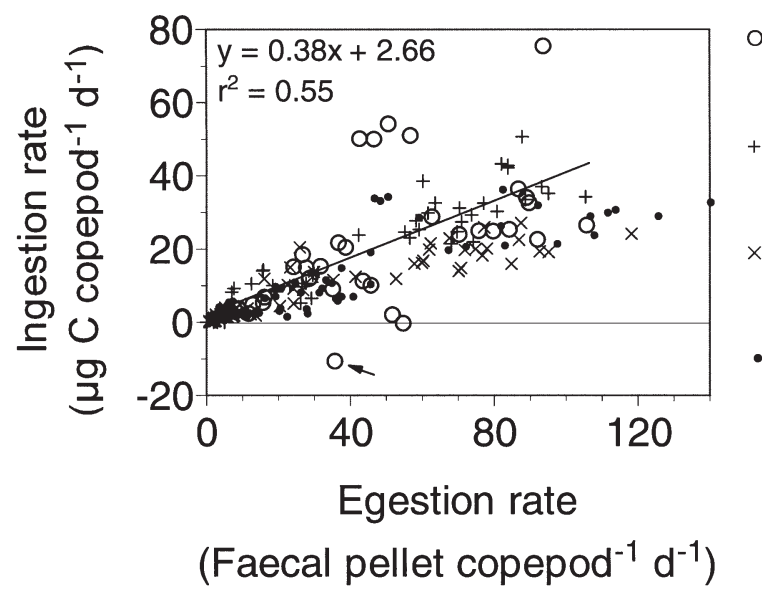

- General correction

$$
y=0.35 x+4.63, r^{2}=0.30, n=33
$$

+ $\quad$ R. baltica (Båmstedt et al. 1999)

$y=0.41 x+1.57, r^{2}=0.86, n=45$

E. huxleyi (Båmstedt et al. 1999)

$=0.25 x+1.29, r^{2}=0.86, n=75$

- $\quad$ North Sea bloom (Gamble 1978)

$y=0.27 x+1.45, r^{2}=0.73, n=59$

Fig. 4. Calanus spp. copepodites V and females. Relationship between ingestion rate and numbers of faecal pellets produced. Results from Expts 96a to 98 (O) based on the General correction (Fig. 2), compared to results from laboratory experiments (Båmstedt et al. 1999) with $C$. finmarchicus feeding on either the coccolithophorid Emiliania huxleyi $(\times)$ or the cryptophyte Rhodomonas baltica (+) as single food species, and field data (Gamble 1978) with C. finmarchicus feeding in a diatom dominated bloom in the North Sea $(\bullet)$. The negative outlier (arrow) was excluded from further analysis. The individual regressions were significantly different from each other ( $\mathrm{p}<0.05$, Chow-test), except for the General correction that was not different from $R$. baltica $(\mathrm{p} \gg 0.5)$, and E. huxleyi versus the North Sea bloom ( $\mathrm{p}>0.5)$. The overall regression for the General correction and $R$. baltica is shown (slope $\mathrm{p} \ll 0.0001$, intercept $\mathrm{p}=0.24, \mathrm{n}=78$ )

lets (cf. Båmstedt et al. 1999), careful collection of the pellets (e.g. using reverse filtration) and application of image analysis to increase the analytical speed and precision of pellet volume determination in future studies.

Variation in assimilation efficiency, pellet packing and density will still limit the precision of volumetric pellet-based methods (cf. Butler \& Dam 1994, Feinberg $\&$ Dam 1998). These errors appear to be relatively large for diatom dominated diets (cf. Fig. 3 and Butler \& Dam 1994) but are still minor compared to the statistically significant negative rates that may be obtained by uncorrected bottle incubations. However, these errors may be reduced by calibration to the specific predator and prey types (as suggested in Båmstedt et al. 1999), and appear to be low for non-diatom diets. Furthermore, volumetric egestion rates have strong advantages compared to other simple methods, such as the gut pigment technique (Mackas \& Bohrer 1976), because they include non-pigmented food (cf. Dam et al. 1994, Peterson \& Dam 1996), and it may be used for repeated measurements of a single individual, e.g. in egg production studies.

Thus we suggest that the most species- and stagespecific equations available, such as those obtained for late stages of Calanus spp. in Fig. 3, may be used to estimate ingestion rates from faecal pellet volume. We also suggest that pellet production should be analysed in incubation experiments with natural plankton, as this provides a robust internal standard for total ingestion rates.

\section{SUMMARY AND CONCLUSIONS}

We have shown that grazing rates based on the uncorrected traditional method were significantly underestimated in some cases due to selective loss of microzooplankton grazing pressure in the copepod bottles. This problem appears to increase when high microzooplankton grazing pressure coincides with high and selective copepod feeding on the microzooplankton.

In contrast, both correction methods appear to yield good copepod feeding estimates, because: (1) corrected copepod feeding rates were never significantly negative, but still low on sub-optimal sized prey, (2) there were no correlations between microzooplankton and corrected copepod feeding rates, but (3) very good fit with volumetric egestion data, and (4) ingestion rates were well within published values for comparable food situations.

We argue that the classical faecal production method provides a simple and quick overall feeding estimate with important advantages over the common gut pigment technique. But this requires that loss and estimation errors are minimised, and that volume egestion rates are adequately calibrated to food environment, stage and species specific ingestion rates. Thus we suggest to routinely include pellet production analysis as a robust internal standard for total ingestion rates in incubation experiments with natural plankton.

The complexity and need for taxonomical accuracy are reduced in the General method, while it still appears to yield estimates as accurate and precise as 
those of the Guild method. Therefore we suggest that the General method of correction should be applied to control for the variable and potentially significant interaction of microzooplankton grazing in future experiments with trophically mixed prey and omnivorous predators. Although the General method of correction requires considerably more experimental effort than the classical uncorrected approach, it also adds information on microzooplankton grazing etc. with a minimal total number of additional experimental bottles. Thus, this is a minimum approach to gain detailed knowledge of the total phytoplankton-zooplankton interactions in natural plankton.

Acknowledgements. We thank the 4 anonymous referees and Prof. Ulf Bàmstedt for their valuable suggestions. We thank Dr Paul J. B. Hart for linguistic corrections. This work is a part in the MARICULT project NAPP and was supported by grants from the Norwegian Research Council for Science and Humanities (NFR) to J.C.N. and L.-J.N., and travel grants from the University of Bergen, Scientific Cooperation Programme with the Russian Academy of Sciences, to A.S.

\section{LITERATURE CITED}

Andersen P, Sørensen HM (1986) Population dynamics and trophic coupling in pelagic microorganisms in eutrophic coastal waters. Mar Ecol Prog Ser 33:99-109

Andersen T, Schartau AKL, Paasche E (1991) Quantifying external and internal nitrogen and phosphorus pools, as well as nitrogen and phosphorus supplied through remineralization, in coastal marine plankton by means of a dilution technique. Mar Ecol Prog Ser 69:1-2

Atkinson A (1994) Diets and feeding selectivity among the epipelagic copepod community near south Georgia in summer. Polar Biol 14:551-560

Atkinson A (1996) Subantarctic copepods in an oceanic, low chlorophyll environment: ciliate predation, food selectivity and impact on prey populations. Mar Ecol Prog Ser 130: 85-96

Atkinson A, Ward P, Murphy EJ (1996) Diel periodicity of subantarctic copepods: relationships between vertical migration, gut fullness and gut evacuation rate. J Plankton Res 18:1387-1405

Ayukai T, Nishizawa S (1986) Defecation rate as a possible measure of ingestion rate of Calanus pacificus pacificus (Copepoda: Calanoida). Bull Plankton Soc Jpn 33:3-10

Båmstedt U (1986) Chemical composition and energy content. In: Corner EDS, O'Hara SCM (eds) The biological chemistry of marine copepods. Oxford University Press, Oxford, p 1-58

Båmstedt U, Håkanson JL, Brenner-Larsen J, Bjørnsen PK, Geertz-Hansen O, Tiselius P (1990) Copepod nutritional condition and pelagic production during autumn in Kosterfjorden, western Sweden. Mar Biol 104:197-208

Båmstedt U, Nejstgaard JC, Solberg PT (1999) Utilisation of small-sized food algae by Calanus finmarchicus (Copepoda, Calanoida) and the significance of feeding history. Sarsia 84:19-38

Båmstedt U, Gifford DJ, Irigoien X, Atkinson A, Roman M (2000) Feeding. In: Harris R, Wiebe P, Lenz J, Skjoldal HR, Huntley M (eds) ICES zooplankton methodology manual. Academic Press, London, p 297-399
Banse K (1974) The nitrogen-to-phosphorous ratio in the photic zone of the sea and the elemental composition of the plankton. Deep-Sea Res 21:767-771

Banse K (1995) Zooplankton: pivotal role in the control of ocean production. ICES J Mar Sci 52:3-4

Blom G, Otterå H, Svåsand T, Kristiansen TS, Serigstad B (1989) The relationship between feeding conditions and production of cod fry (Gadus morhua) in a semi-enclosed marine ecosystem in western Norway, illustrated by use of a consumption model. ICES Mar Sci Symp 192:176-189

Braarud T, Gaarder KR, Nordli O (1958) Seasonal changes in the phytoplankton at various points off the Norwegian west coast. Fiskeridir Skr Ser Havunders 12:1-76

Bralewska JM, Witek Z (1995) Heterotrophic dinoflagellates in the ecosystem of the Gulf of Gdansk. Mar Ecol Prog Ser 117:241-248

Bronk DA, Ward BB (2000) Magnitude of dissolved organic nitrogen release relative to gross nitrogen uptake in marine systems. Limnol Oceanogr 45:1879-1883

Butler M, Dam HG (1994) Production rates and characteristics of fecal pellets of the copepod Acartia tonsa under simulated phytoplankton bloom conditions: implications for vertical fluxes. Mar Ecol Prog Ser 114:81-91

Calbet A, Landry MR (1999) Mesozooplankton influences on the microbial food web: direct and indirect trophic interactions in the oligotrophic open ocean. Limnol Oceanogr 44:1370-1380

Caron DA (1983) Technique for enumeration of heterotrophic nanoplankton, using epifluoriscence microscopy, and comparison with other procedures. Appl Environ Microbiol 46:491-498

Dam HG, Peterson WT, Bellantoni DC (1994) Seasonal feeding and fecundity of the calanoid copepod Acartia tonsa in Long Island Sound: is omnivory important to egg production? Hydrobiologia 292-293:191-199

Dolan JR (1991) Guilds of ciliate microzooplankton in the Chesapeake Bay. Estuar Coast Shelf Sci 33:137-152

Dolan JR, Coats DW (1991) A study of feeding in predacious ciliates using prey ciliates labeled with fluorescent microspheres. J Plankton Res 13:609-627

Drebes G (1974) Marines phytoplankton: eine Auswahl der Helgoländer Planktonalgen (Diatomeen, Peridineen). Georg Thieme Verlag, Stuttgart

Edler L (1979) Recommendations for marine biological studies in the Balt Sea: phytoplankton and chlorophyll. Baltic Mar Biol Publ 5:38

Elbrächter M (1973) Population dynamics of Ceratium in coastal waters of the Kiel bay. Oikos 15:43-48

Falkowski PG (2000) Rationalizing elemental ratios in unicellular algae. J Phycol 36:3-6

Feinberg LR, Dam HG (1998) Effects of diet on dimensions, density and sinking rates of fecal pellets of the copepod Acartia tonsa. Mar Ecol Prog Ser 175:87-96

Fessenden L, Cowles TJ (1994) Copepod predation on phagotrophic ciliates in Oregon coastal waters. Mar Ecol Prog Ser 107:1-2

Frost BW (1972) Effect of size and concentration of food particles on the feeding behaviour of the marine planktonic copepod Calanus pacificus. Limnol Oceanogr 17:805-815

Gaines G, Elbrächter M (1987) Heterotrophic nutrition. In: Taylor FJR (ed) The biology of dinoflagellates. Botanical Monographs 21, Blackwell Scientific Publications, Oxford, p 224-268

Gallegos CL (1989) Microzooplankton grazing on phytoplankton in the Rhode River, Maryland: nonlinear feeding kinetics. Mar Ecol Prog Ser 57:23-33

Gamble J (1978) Copepod grazing during a declining spring 
phytoplankton bloom in the northern North Sea. Mar Biol 49:303-315

Games PA, Howell JF (1976) Pairwise multiple comparison procedures with unequal $n$ 's and/or variances: a Monte Carlo study. J Edu Stat 1:113-125

Gaudy R (1974) Feeding four species of pelagic copepods under experimental conditions. Mar Biol 25:125-141

Gifford DJ (1991) The protozoan-metazoan trophic link in pelagic ecosystems. J Protozool 38:81-86

Gifford DJ (1993) Consumption of protozoa by copepods feeding on natural microplankton assemblages. In: Kemp PF, Sherr BF, Sherr EB, Cole JJ (eds) Handbook of methods in aquatic microbial ecology. Lewis Publishers, Boca Raton, FL, p 723-729

Glibert PM (1998) Interactions of top-down and bottom-up control in planktonic nitrogen cycling. Hydrobiologia 363: $1-12$

Godhantaraman N, Krishnamurthy K (1997) Experimental studies on food habits of tropical microzooplankton: (Preypredator interrelationship). Indian J Mar Sci 26:345-349

González HE, Ortiz VC, Sobarzo M (2000) The role of faecal material in the particulate organic carbon flux in the northern Humboldt Current, Chile $\left(23^{\circ} \mathrm{S}\right)$, before and during the 1997-1998 El Niño. J Plankton Res 22:499-529

Grebecki A (1962) Adsorbtion des fluorochromes par le cystome des Cillies. Bull Acad Pol Sci 10:483-485

Gustafson DE, Stoecker DK, Johnson MD, van Heukelem WF, Sneider K (2000) Cryptophyte algae are robbed of their organelles by the marine ciliate Mesodinium rubrum. Nature 405:1049-1052

Hansen B, Bjørnsen PK, Hansen PJ (1994) The size ratio between planktonic predators and their prey. Limnol Oceanogr 39:395-403

Hansen FC, Reckermann M, Breteler WCMK, Riegman R (1993) Phaeocystis blooming enhanced by copepod predation on protozoa: evidence from incubation experiments. Mar Ecol Prog Ser 102:51-57

Hansen PJ (1991) Dinophysis - a planktonic dinoflagellate genus which can act both as a prey and a predator of a ciliate. Mar Ecol Prog Ser 69:201-204

Hansen PJ, Calado AJ (1999) Phagotrophic mechanisms and prey selection in free-living dinoflagellates. J Eukaryot Microbiol 46:382-389

Hansen PJ, Bjørnsen PK, Hansen BW (1997) Zooplankton grazing and growth: scaling within the $2-2,000-\mu \mathrm{m}$ body size range. Limnol Oceanogr 42:687-704

Harris RP (1994) Zooplankton grazing on the coccolithophore Emiliania huxleyi and its role in inorganic carbon flux. Mar Biol 119:431-439

Heimdal BR, Reisegg AB (1996) Phytoplankton surveys of Korsfjorden, western Norway, in 1978-1984 biomass, productivity and species composition. IFM Rapp, Department of Fisheries and Marine Biology, University of Bergen

Hobbie JE, Daley RJ, Jasper S (1977) Use of nucleopore filters for counting bacteria by fluorescence microscopy. Appl Environ Microbiol 33:1225-1228

Jacobson DM, Anderson DM (1996) Widespread phagocytosis of ciliates and other protists by marine mixotrophic and heterotrophic thecate dinoflagellates. J Phycol 32: 279-285

Jeong HJ (1994) Predation by the heterotrophic dinoflagellate Protoperidinium cf. divergens on copepod eggs and early naupliar stages. Mar Ecol Prog Ser 114:203-208

Jonsson PR (1986) Particle size selection, feeding rates and growth dynamics of marine planktonic oligotrichous ciliates (Ciliophora: Oligotrichina). Mar Ecol Prog Ser 33: 265-277
Juhl AR, Ohman MD, Goericke R (1996) Astaxanthin in Calanus pacificus: assessment of pigment-based measures of omnivory. Limnol Oceanogr 41:1198-1207

Karlson K, Båmstedt U (1994) Planktivorous predation on copepods. Evaluation of mandible remains in predator guts as a quantitative estimate of predation. Mar Ecol Prog Ser 108:79-89

Kivi K, Setälä O (1995) Simultaneous measurement of food particle selection and clearance rates of planktonic oligotrich ciliates (Ciliophora: Oligotrichina). Mar Ecol Prog Ser 119:1-3

Kleppel GS (1993) On the diets of calanoid copepods. Mar Ecol Prog Ser 99:183-195

Kleppel GS, Pieper RE (1984) Phytoplankton pigments in the gut contents of planktonic copepods from coastal waters off southern California. Mar Biol 78:193-198

Koutsoyiannis A (1977) Theory of econometrics: an introductory exposition of econometric methods. Macmillan Press Ltd, Hong Kong

Landry MR (1993) Estimating rates of growth and grazing mortality of phytoplankton by the dilution method. In: Kemp PF, Sherr BF, Sherr EB, Cole JJ (eds) Handbook of methods in aquatic microbial ecology. Lewis Publishers, Boca Raton, FL, p 715-722

Landry MR, Fagerness VL (1988) Behavioral and morphological influences on predatory interactions among marine copepods. Bull Mar Sci 43:509-529

Laval-Peuto M, Rassoulzadegan F (1988) Autofluorescence of marine planktonic Oligotrichina and other ciliates. Hydrobiologia 159:99-110

Lehman JT (1980) Release and cycling of nutrients between planktonic algae and herbivores. Limnol Oceanogr 25: 620-632

Lessard EJ, Swift E (1986) Dinoflagellates from the North Atlantic classified as phototrophic or heterotrophic by epifluorescence microscopy. J Plankton Res 8:1209-1215

Mackas DL, Bohrer R (1976) Fluorescence analysis of zooplankton gut contents and an investigation of diel feeding patterns. J Exp Mar Biol Ecol 25:77-85

Manly BFJ (1974) A model for certain types of selection experiments. Biometrics 30:281-294

Marin V, Huntley ME, Frost B (1986) Measuring feeding rates of pelagic herbivores: analysis of experimental design and methods. Mar Biol 93:49-58

Marshall SM, Orr AP (1955) On the biology of Calanus finmarchicus. VIII. Food uptake, assimilation and excretion in adult and stage V Calanus. J Mar Biol Assoc UK 34: 495-529

Menden-Deuer S, Lessard EJ (2000) Carbon to volume relationships for dinoflagellates, diatoms, and other protist plankton. Limnol Oceanogr 45:569-579

Meyer-Harms B, Irigoien X, Head R, Harris R (1999) Selective feeding on natural phytoplankton by Calanus finmarchicus before, during, and after the 1997 spring bloom in the Norwegian Sea. Limnol Oceanogr 44:154-165

Montagnes DJS (1986) Growth responses of planktonic ciliates in the genera Strobilidium and Strombidium. Mar Ecol Prog Ser 130:241-254

Nakamura Y, Turner JT (1997) Predation and respiration by the small cyclopoid copepod Oithona similis: wow important is feeding on ciliates and heterotrophic flagellates? J Plankton Res 19:1275-1288

Nejstgaard JC, Witte HJ, van der Wal P, Jacobsen A (1994) Copepod grazing during a mesocosm study of an Emiliania huxleyi (Prymnesiophyceae) bloom. Sarsia 79:369-377

Nejstgaard JC, Båmstedt U, Bagøien E, Solberg PT (1995) Algal constraints on copepod grazing growth state, 
toxicity, cell size, and season as regulating factors. ICES J Mar Sci 52:347-357

Nejstgaard JC, Gismervik I, Solberg PT (1997) Feeding and reproduction by Calanus finmarchicus, and microzooplankton grazing during mesocosm blooms of diatoms and the coccolithophore Emiliania huxleyi. Mar Ecol Prog Ser 147:197-217

Nielsen TG, Kiørboe T (1994) Regulation of zooplankton biomass and production in a temperate, coastal ecosystem. 2. Ciliates. Limnol Oceanogr 39:508-519

Noji TT, Estep KW, MacIntyre F, Norrbin F (1991) Image analysis of faecal material grazed upon by three species of copepods: evidence for coprorhexy, coprophagy and coprochaly. J Mar Biol Assoc UK 71:465-480

Ohman MD (1992) Immunochemical recognition of oligotrich ciliates. Mar Biol 114:653-660

Ohman MD, Runge JA (1994) Sustained fecundity when phytoplankton resources are in short supply: omnivory by Calanus finmarchicus in the Gulf of St. Lawrence. Limnol Oceanogr 39:21-36

Ohman MD, Snyder RA (1991) Growth-kinetics of the omnivorous oligotrich ciliate Strombidium sp. Limnol Oceanogr 36:922-935

Omori M, Ikeda T (1984) Methods in marine zooplankton ecology, 1st edn, John Wiley \& Sons, New York

Paasche E, Østergren I (1980) The annual cycle of plankton diatom growth and silica production in the inner Oslofjord. Limnol Oceanogr 25:481-494

Perez MT, Dolan JR, Fukai E (1997) Planktonic oligotrich ciliates in the NW Mediterranean: growth rates and consumption by copepods. Mar Ecol Prog Ser 155:89-101

Peterson WT, Dam HG (1996) Pigment ingestion and egg production rates of the calanoid copepod Temora longicornis: implications for gut pigment loss and omnivorous feeding. J Plankton Res 18:855-861

Putland JN (2000) Microzooplankton herbivory and bacterivory in Newfoundland coastal waters during spring, summer and winter. J Plankton Res 22:253-277

Putt M, Stoecker DK (1989) An experimentally determined carbon: volume ratio for marine 'oligotrichous' ciliates from estuarine and coastal waters. Limnol Oceanogr 34: 1097-1103

Roman MR, Gauzens AL (1997) Copepod grazing in the Equatorial Pacific. Limnol Oceanogr 42:623-634

Roman MR, Rublee PA (1980) Containment effects in copepod grazing experiments: a plea to end the black box approach. Limnol Oceanogr 25:982-990

Roman MR, Rublee PA (1981) A method to determine in situ zooplankton grazing rates on natural particle assemblages. Mar Biol 65:303-309

Roman M, Smith S, Wishner K, Zhang X, Gowing M (2000) Mesozooplankton production and grazing in the Arabian Sea. Deep-Sea Res Part II Top Stud Oceanogr 47:1423-1450

Rousseau V, Mathot S, Lancelot C (1990) Calculating carbon biomass of Phaeocystis sp. from microscopic observations. Mar Biol 107:305-314

Sime-Ngando T, Gosselin M, Roy S, Chanut JP (1995) Significance of planktonic ciliated protozoa in the Lower St. Lawrence Estuary: comparison with bacterial, phytoplankton, and particulate organic carbon. Aquat Microb Ecol 9:243-258

Sommer U (1988) Phytoplankton succession in microcosm experiments under simultaneous grazing pressure and resource limitation. Limnol Oceanogr 33:1037-1054
Stoecker DK, Capuzzo JM (1990) Predation on protozoa: its importance to zooplankton. J Plankton Res 12:891-908

Stoecker DK, Egloff DA (1987) Predation by Acartia tonsa Dana on planktonic ciliates and rotifers. J Exp Mar Biol Ecol 110:53-68

Stoecker DK, Evans GT (1985) Effects of protozoan herbivory and carnivory in a microplankton food web. Mar Ecol Prog Ser 25:159-167

Stoecker D, Guillard RRL, Kavee RM (1981) Selective predation by Favella ehrenbergii (Tintinnia) on and among dinoflagellates. Biol Bull 160:136-145

Stoecker DK, Silver MW, Michaels AE, Davis LH (1988) Obligate mixotrophy in Laboea strobila, a ciliate which retains chloroplasts. Mar Biol 99:415-423

Stoecker DK, Silver MW, Michaels AE, Davis LH (1989) Enslavement of algal chloroplasts by four Strombidium spp. (Ciliophora, Oligotrichida). Mar Microb Food Webs 3: 79-100

Stoecker DK, Gifford DJ, Putt M (1994) Preservation of marine planktonic ciliates: losses and cell shrinkage during fixation. Mar Ecol Prog Ser 110:293-299

Strom SL, Buskey EJ (1993) Feeding, growth, and behavior of the thecate heterotrophic dinoflagellate Oblea rotunda. Limnol Oceanogr 38:965-977

Svensen C, Egge JK, Stiansen JE (2001) Can silicate and turbulence regulate the vertical flux of biogenic matter? A mesocosm study. Mar Ecol Prog Ser 217:67-80

Tamigneaux E, Mingelbier M, Klein B (1997) Grazing by protists and seasonal changes in the size structure of protozooplankton and phytoplankton in a temperate nearshore environment (western Gulf of St. Lawrence, Canada). Mar Ecol Prog Ser 146:231-247

Taylor FJR, Fukuyo Y, Larsen J (1995) Taxonomy of harmful dinoflagellates. In: Hallegraeff GM, Anderson DM, Cembella AD (eds) Manual on harmful marine microalgae. UNESCO, Paris, p 283-317

Tomas CR (ed) (1997) Identifying marine phytoplankton. Academic Press, San Diego

Tong SM, Nygaard K, Bernard C, Vørs N, Patterson DJ (1998) Heterotrophic flagellates from the water column in Port Jackson, Sydney, Australia. Eur J Protistol 34:162-194

Turner JT, Tester PA, Conley WJ (1984) Zooplankton feeding ecology: predation by the marine cyclopoid copepod Corycaeus amazonicus F. Dahl upon natural prey. J Exp Mar Biol Ecol 84:191-202

Turner JT, Tester PA, Hettler WF (1985) Zooplankton feeding ecology: a laboratory study of predation on fish eggs and larvae by the copepods Anomalocera ornata and Centropages typicus. Mar Biol 90:1-8

Urban JL, Deibel D, Schwinghamer P (1993) Seasonal variations in the densities of fecal pellets produced by Oikopleura vanhoeffeni (Larvacea) and Calanus finmarchicus (Copepoda). Mar Biol 117:607-613

Verity PG, Paffenhöfer GA (1996) On assessment of prey ingestion by copepods. J Plankton Res 18:1767-1779

Welschmeyer NA (1994) Fluorometric analysis of chlorophyll $a$ in the presence of chlorophyll $b$ and pheopigments. Limnol Oceanogr 39:1985-1992

Widdows J (1991) Physiological ecology of mussel larvae. Aquaculture 94:2-3

Williams PJLB, Egge JK (1998) The management and behaviour of the mesocosms. Estuar Coast Shelf Sci 46:3-14

Zar JH (1996) Biostatistical analysis, 3rd edn. Prentice Hall, Upper Saddle River, NJ

Submitted: July 24, 2000; Accepted: July 5, 2001

Proofs received from author(s): September 27, 2001 